\title{
FS CEIVED
}

\section{JAN 251996 \\ $\theta$ STI}

Contamination Source Review for Building E2370, Edgewood Area, Aberdeen Proving Ground, Maryland

Energy Systems Division

Argonne National Laboratory

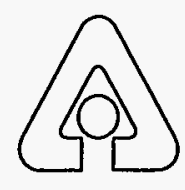

Operated by The University of Chicago,

under Contract W-31-109-Eng-38, for the

United States Department of Energy 


\section{Argonne National Laboratory}

Argonne National Laboratory, with facilities in the states of Illinois and Idaho, is owned by the United States Government, and operated by the University of Chicago under the provisions of a contract with the Department of Energy.

This technical memo is a product of Argonne's Energy Systems (ES) Division. For information on the division's scientific and engineering activities, contact:

Director, Energy Systems Division

Argonne National Laboratory

Argonne, Illinois 60439-4815

Telephone (708) 252-3724

Presented in this technical memo are preliminary results of ongoing work or work that is more limited in scope and depth than that described in formal reports issued by the ES Division.

Publishing support services were provided by Argonne's Information and Publishing Division (for more information, see IPD's home page: http://www.ipd.anl.gov/)

\section{Disclaimer}

This report was prepared as an account of work sponsored by an agency of the United States Government. Neither the United States Government nor any agency thereof, nor any of their employees, makes any warranty, express or implied, or assumes any legal liability or responsibility for the accuracy, completeness, or usefulness of any information, apparatus, product, or process disclosed, or represents that its use would not infringe privately owned rights. Reference herein to any specific commercial product, process, or service by trade name, trademark, manufacturer, or otherwise, does not necessarily constitute or imply its endorsement, recommendation, or favoring by the United States Government or any agency thereof. The views and opinions of authors expressed herein do not necessarily state or reflect those of the United States Government or any agency thereof.

Reproduced directly from the best available copy.

Available to DOE and DOE contractors from the Office of Scientific and Technical Information, P.O. Box 62, Oak Ridge, TN 37831; prices available from (423) $576-8401$

Available to the public from the National Technical Information Service, U.S. Department of Commerce, 5285 Port Royal Road, Springfield, VA 22161. 


\section{Contamination Source Review for Building E2370, Edgewood Area, Aberdeen Proving Ground, Maryland}

D.P. O'Reilly, M.A. Glennon, A.K. Draugelis, J..Rueda, and R.E. Zimmerman

Center for Environmental Restoration Systems, Energy Systems Division, Argonne National Laboratory, 9700 South Cass Avenue, Argonne, Illinois 60439

\section{Published as}

Contamination Source Review Edgewood Area, Aberdeen Proving Ground, Maryland Building E2370

Work sponsored by United States Department of Defense, United States Army, Aberdeen Proving Ground, Maryland

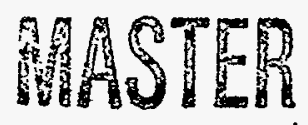


This report is printed on recycled paper. 


\section{Contents}

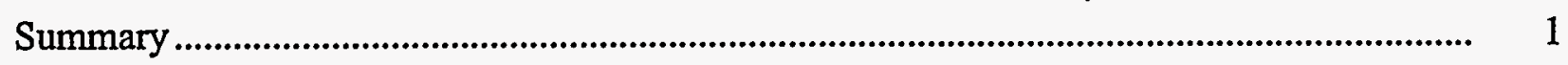

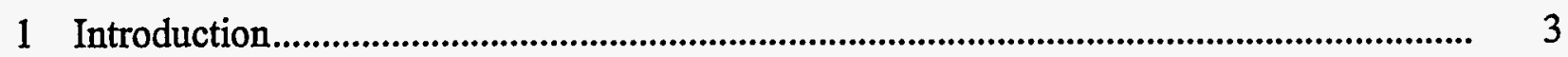

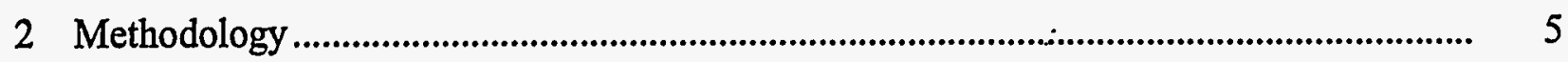

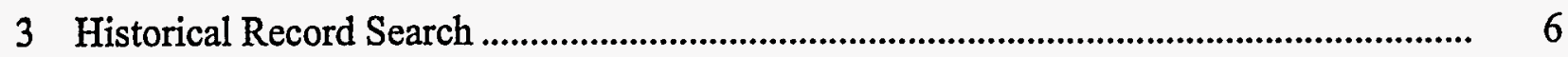

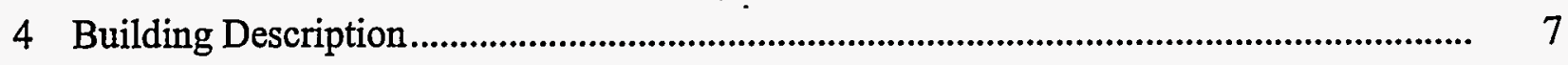

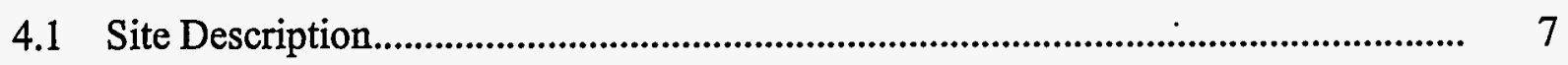

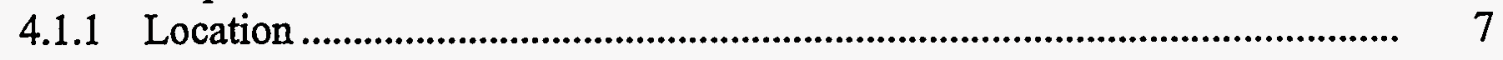

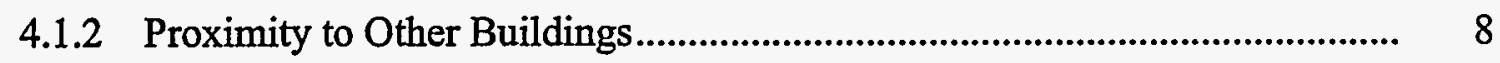

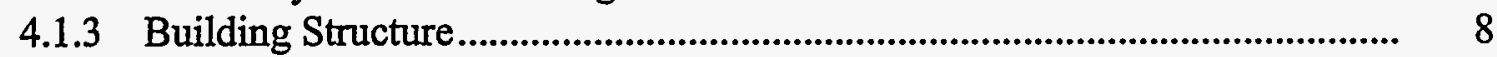

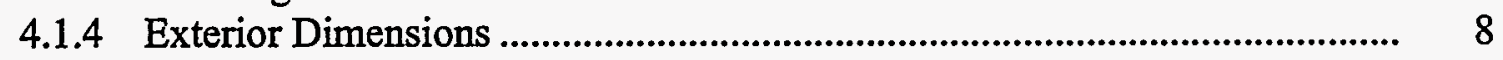

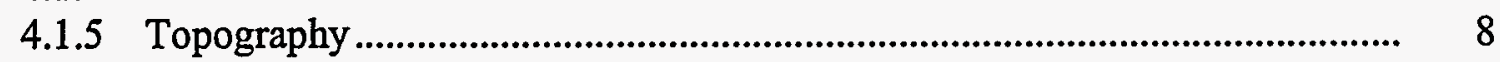

4.1.6 Vegetation in the Immediate Vicinity ..................................................... 8

4.1.7 External Aboveground Structures or Equipment...................................... 11

4.1.8 Connections with Adjacent Buildings.................................................. 11

4.1.9 Underground Structures ...................................................................... 11

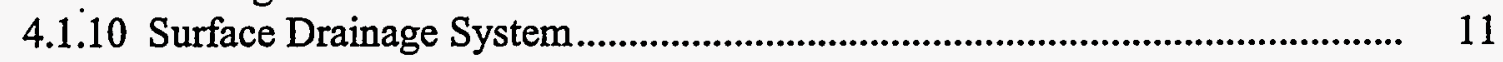

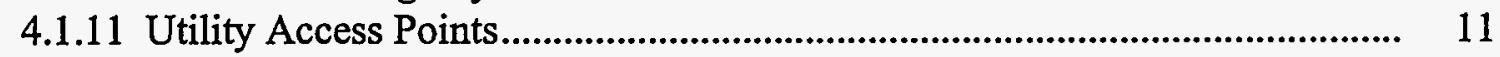

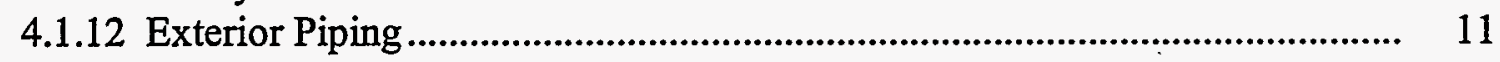

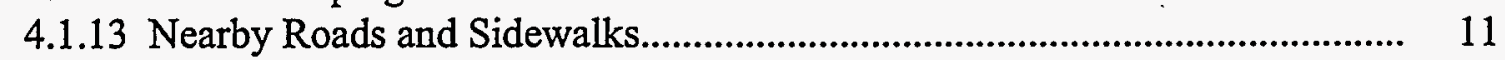

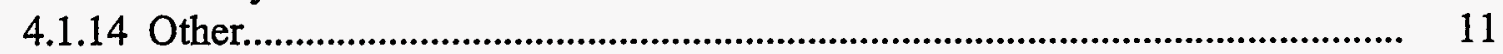

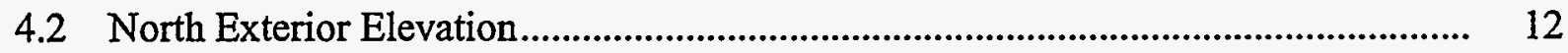

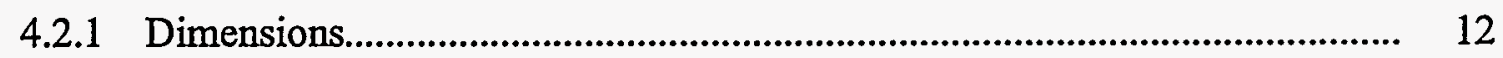

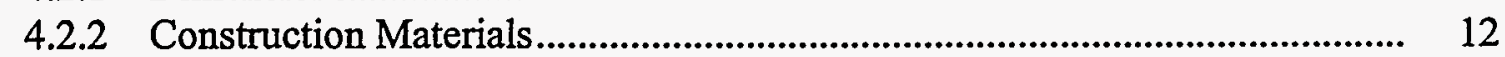

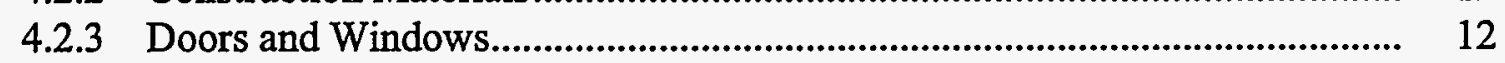

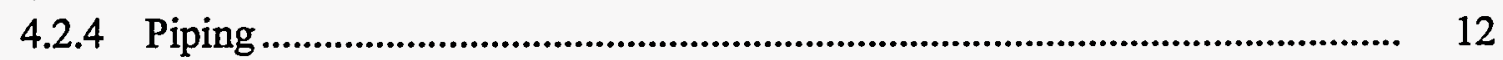

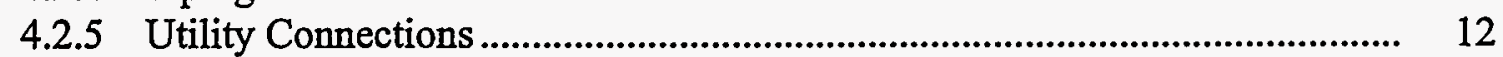

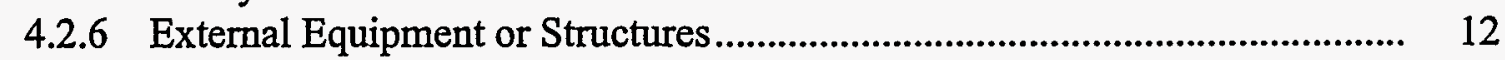

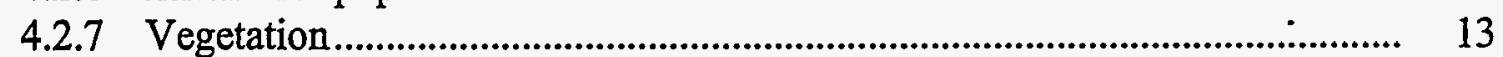

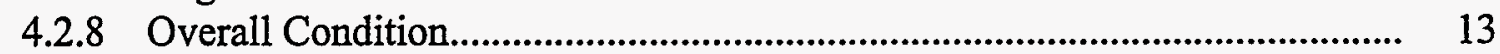

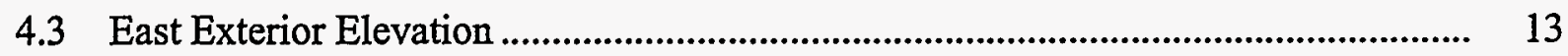

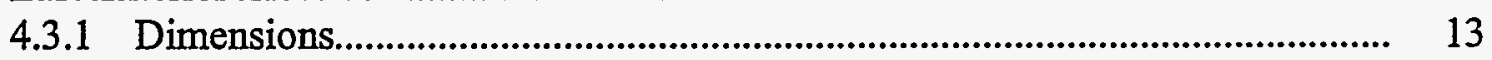

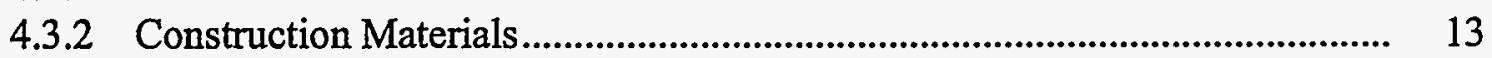

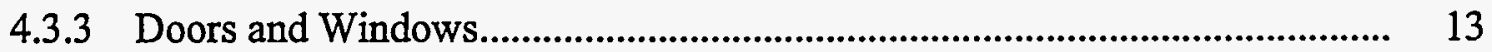

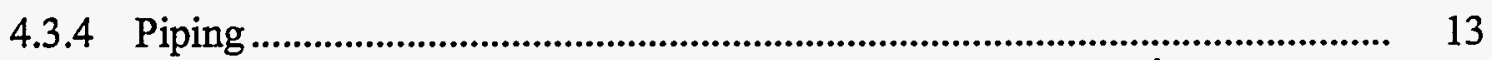

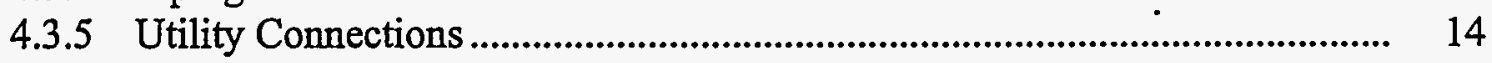

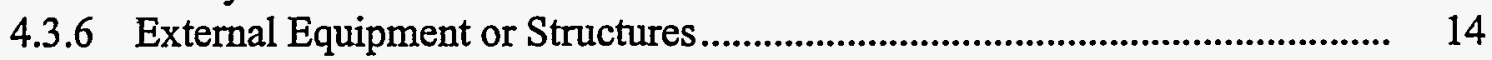

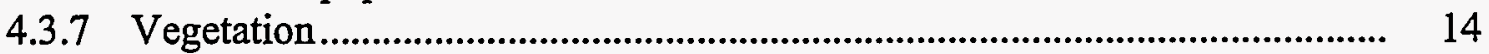

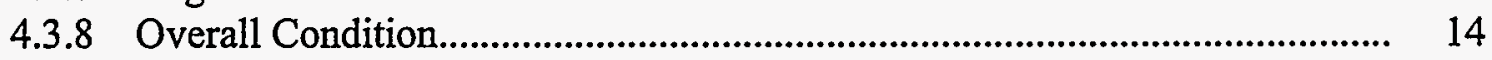




\section{Contents (Cont.)}

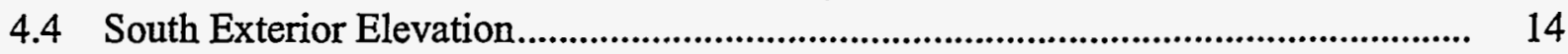

4.4.1 Dimensions.................................................................................. 14

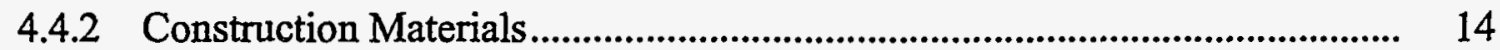

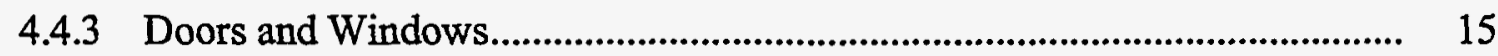

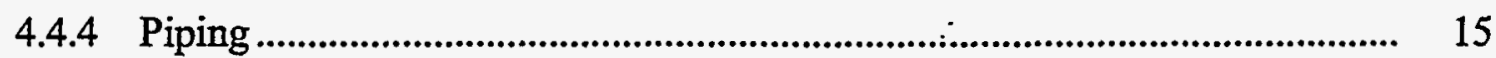

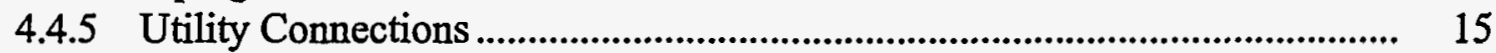

4.4.6 External Equipment or Structures....................................................... 15

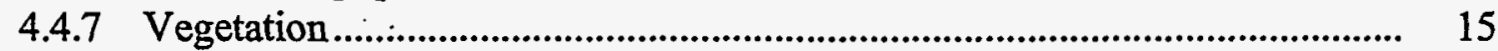

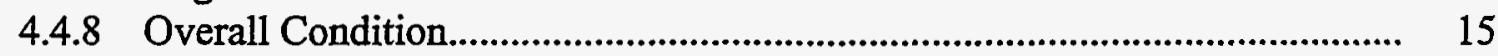

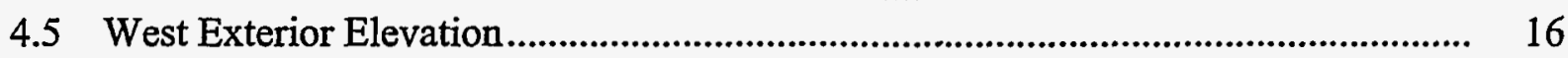

4.5.1 Dimensions....................................................................................... 16

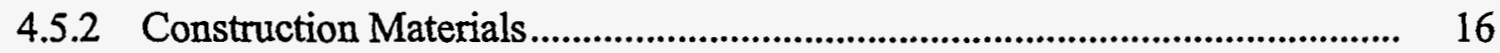

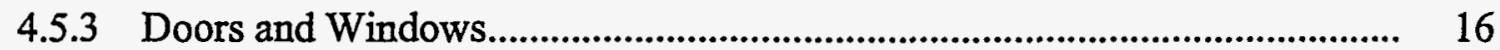

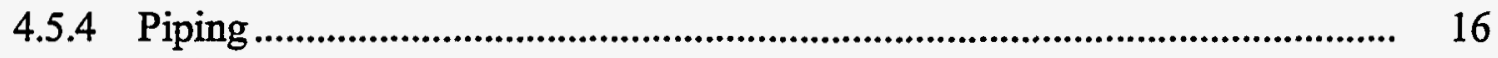

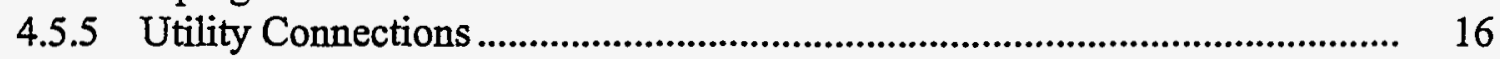

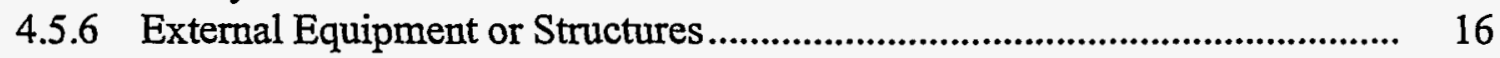

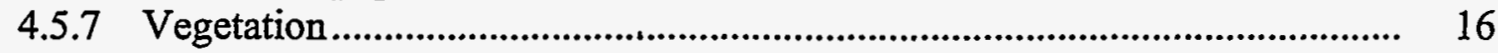

4.5.8 Overall Condition............................................................................ 17

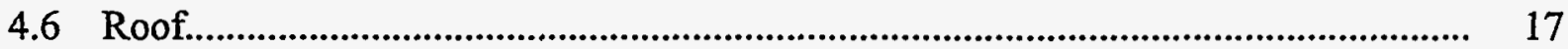

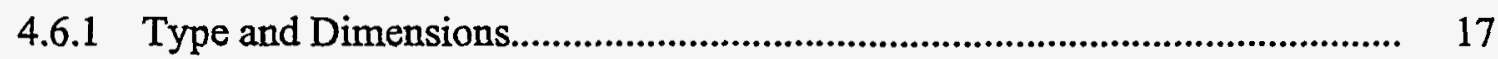

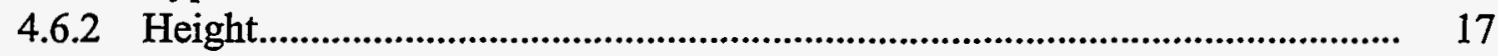

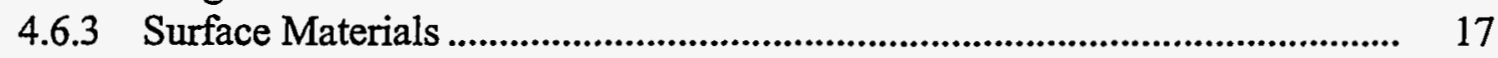

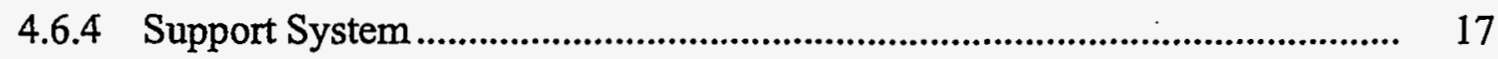

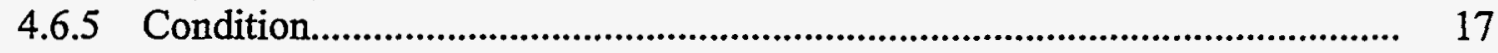

4.6.6 Equipment Located on the Roof ............................................................ 18

4.6.7 Chimneys, Roof Vents, or Vent Stacks................................................... 18

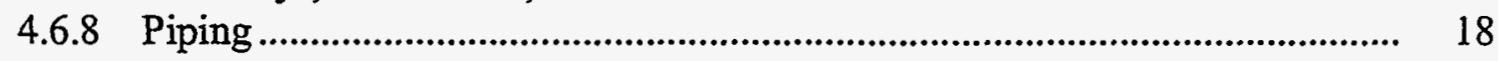

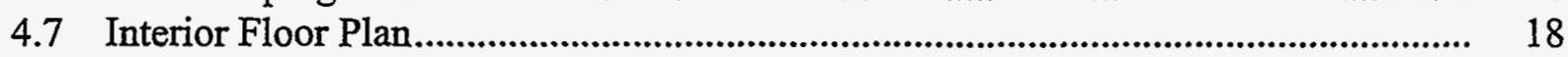

4.7.1 Room Numbers and Dimensions .................................................... 18

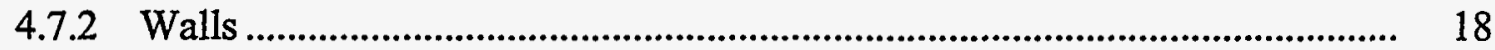

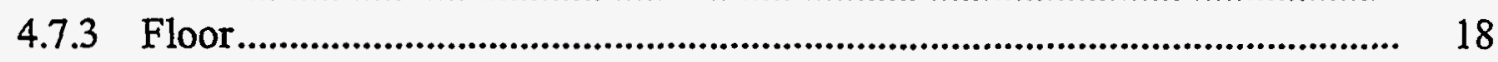

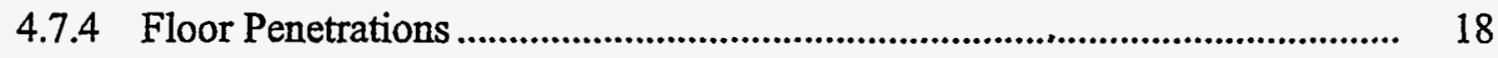

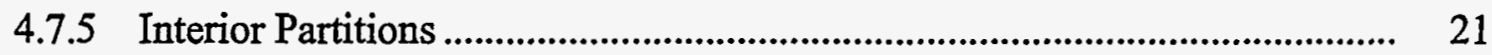

4.7.6 Equipment or Supplies.................................................................. 21

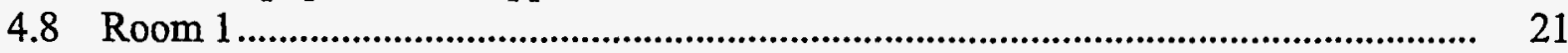

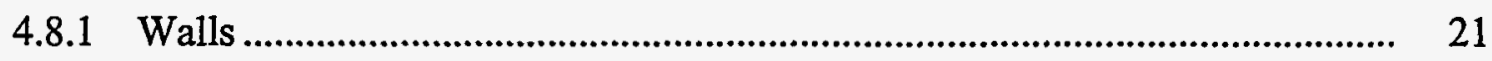

4.8.2 Finish Materials............................................................................... 21

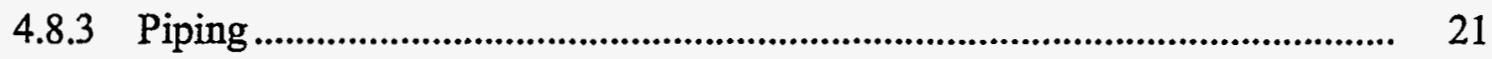

4.8.4 Equipment......................................................................................... 21

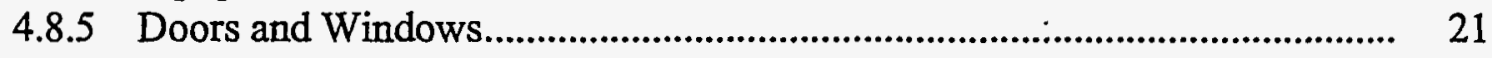

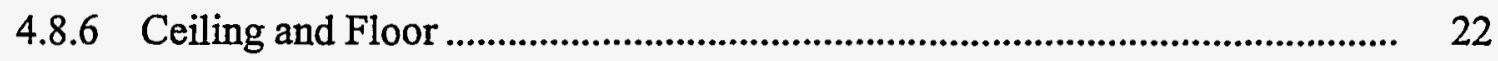




\section{Contents (Cont.)}

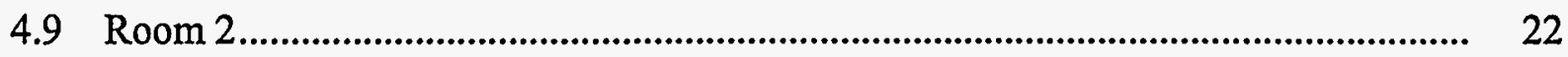

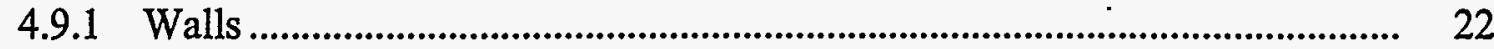

4.9.2 Finish Materials...................................................................................... 22

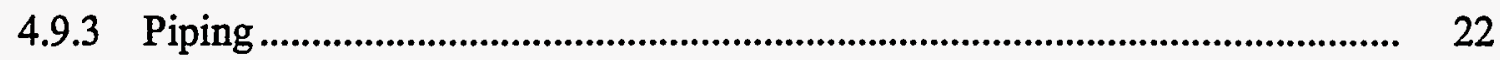

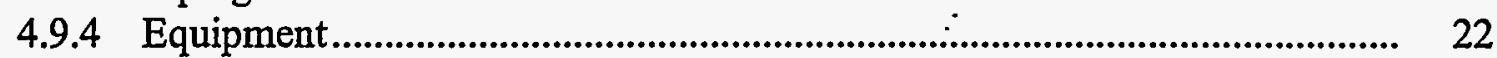

4.9.5 Doors and Windows............................................................................... 22

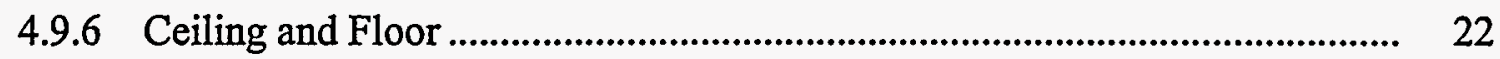

5 Geophysical Investigation......................................................................................... 23

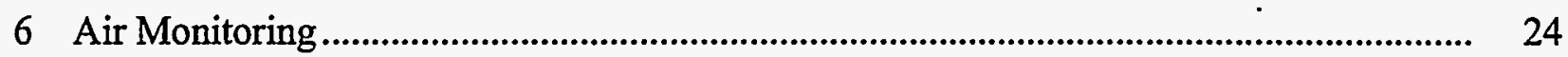

7 Underground Storage Tanks .............................................................................................. 25

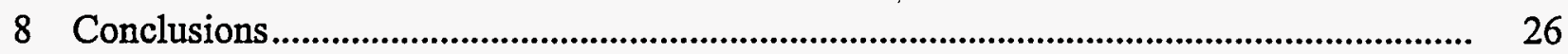

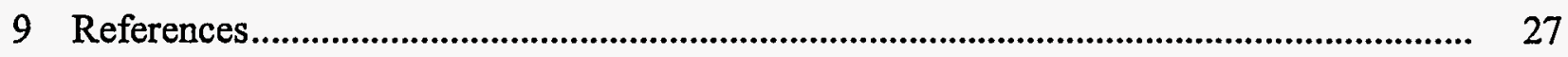

Appendix: Interim Progress Report - Environmental Geophysics:

Building E2370 Decommissioning, Aberdeen Proving Ground............................... 29

\section{Figures}

1 Map of Aberdeen Proving Ground Location .......................................................................

2 Map of Building E2370 Location ...................................................................................... 7

3 Building E2370 Floor Plan .................................................................................. 9

4 Photographs of Building E2370 Exterior...................................................................... 10

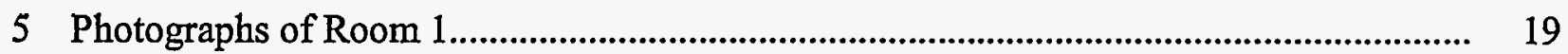

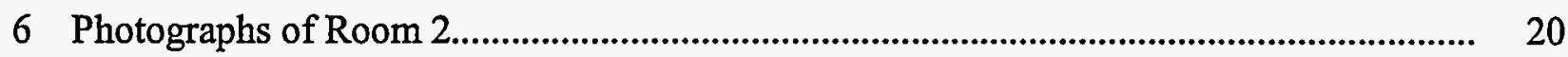





\title{
Contamination Source Review for Building E2370, Edgewood Area, Aberdeen Proving Ground, Maryland
}

\author{
by \\ D.P. O'Reilly, M.A. Glennon, \\ A.K. Draugelis, J. Rueda, and R.E. Zimmerman
}

\section{Summary}

This report was prepared by Argonne National Laboratory (ANL) to document the results of a contamination source review of Building E2370 at the Aberdeen Proving Ground (APG) in Maryland. This report may be used to assist the U.S. Army in planning for the future use or disposition of this building. The review included a historical records search, physical inspection, photographic documentation, and geophysical investigation. The field investigations were performed by ANL during 1994 and 1995.

The historical records search indicated that Building E2370 (APG designation), originally known as Building 934, is located in the old Toxic Gas Yard (TGY) or the Bush River Area Radioactive Material Disposal Facility (BRRMDF). Both of these are in an area of the site that is presently referred to as the Chemical Agent Storage Yard (CASY) in APG's Edgewood Area (Nemeth 1989).

According to historical records (EAI Corporation 1989), Building E2370 was constructed in 1931. The building, a roofed concrete pit divided into two sections, was originally used as a white phosphorus (WP) bulk storage facility or vault. Building E2370 has also been used as a storage site for adamsite and chloroacetophenone and was listed as part of the radiological waste drum shop.

A physical inspection and photographic documentation of Building E2370 were made by ANL staff during November 1994. Included in this report is photographic documentation of the exterior and interior walls and the condition of the building. At the time of the inspection, part of the south wall was damaged and the roof over the south portion of Building E2370 had collapsed, but the major portion of the building was still standing. This single-story, roofed concrete pit measures $62 \mathrm{ft}$ long and $54 \mathrm{ft}$ wide. The floor of the vaults is approximately $6 \mathrm{ft}$ below ground level and the walls rise $10 \mathrm{ft}$ above the floor level. The floors are $18 \mathrm{in}$. thick, the exterior walls are 12 in. thick, and the center dividing wall is 24 in. thick. The interior and exterior walls are made of concrete and extend approximately $4 \mathrm{ft}$ above ground level. The corrugated metal roof has a steel frame supported by concrete columns on top of the walls; the columns are spaced $15 \mathrm{ft} 3$ in. apart. Evidence of plumbing, heating, or electrical connections or floor drains was observed inside the building during the ANL inspection. 
During December 1994, ANL staff conducted geophysical surveys in the immediate vicinity of Building E2370 by using several nonintrusive methods. Survey results suggest the presence of some underground objects near Building E2370, but they do not provide conclusive evidence of the source(s) of the anomalies observed during the surveys.

No information on air quality or underground storage tanks associated with Building E2370 is available.

On the basis of the information collected and reviewed for Building E2370 by ANL, it is the authors' judgment that the geophysical anomalies in the vicinity of Building E2370 warrant further investigation and evaluation. 


\section{Introduction}

The U.S. Army Aberdeen Proving Ground (APG) commissioned Argonne National Laboratory (ANL) to conduct a contamination source review to identify and define areas of toxic or hazardous contaminants and to assess the physical condition and accessibility of APG buildings (Brubaker et al. 1994). The information obtained from this review may be used to assist the U.S. Army in planning for the future use or disposition of the buildings. The contamination source review consisted of the following tasks: historical records search, physical inspection, photographic documentation, and geophysical investigation. This report provides the results of the contamination source review for Building E2370.

Located on Chesapeake Bay in Harford and Baltimore counties, Maryland, APG occupies approximately 30,000 acres. The facility is divided into the Aberdeen and Edgewood areas (Figure 1). The primary mission at APG has been the testing and evaluation of U.S. Army warfare materials. Since its beginning in 1917, the Edgewood Area of APG has been the principal location for chemical warfare agent research, development, and testing in the United States. APG was also used for producing chemical warfare agents during both world wars and has been a center for the storage of chemical warfare material (Nemeth 1989).

Many of the APG facilities constructed between 1917 and the 1960s are no longer used because of obsolescence and their poor state of repair. Because many of these buildings were used for research, development, testing, and/or pilot-scale production of chemical warfare agents and other military substances (such as incendiary materials or munitions containing these materials), the potential exists for portions of the buildings to be contaminated with these substances, their degradation products, and other laboratory or industrial chemicals. These buildings and associated structures or appurtenances (e.g., underground or aboveground storage tanks, pipes, sumps) may contribute to environmental concerns at APG. 


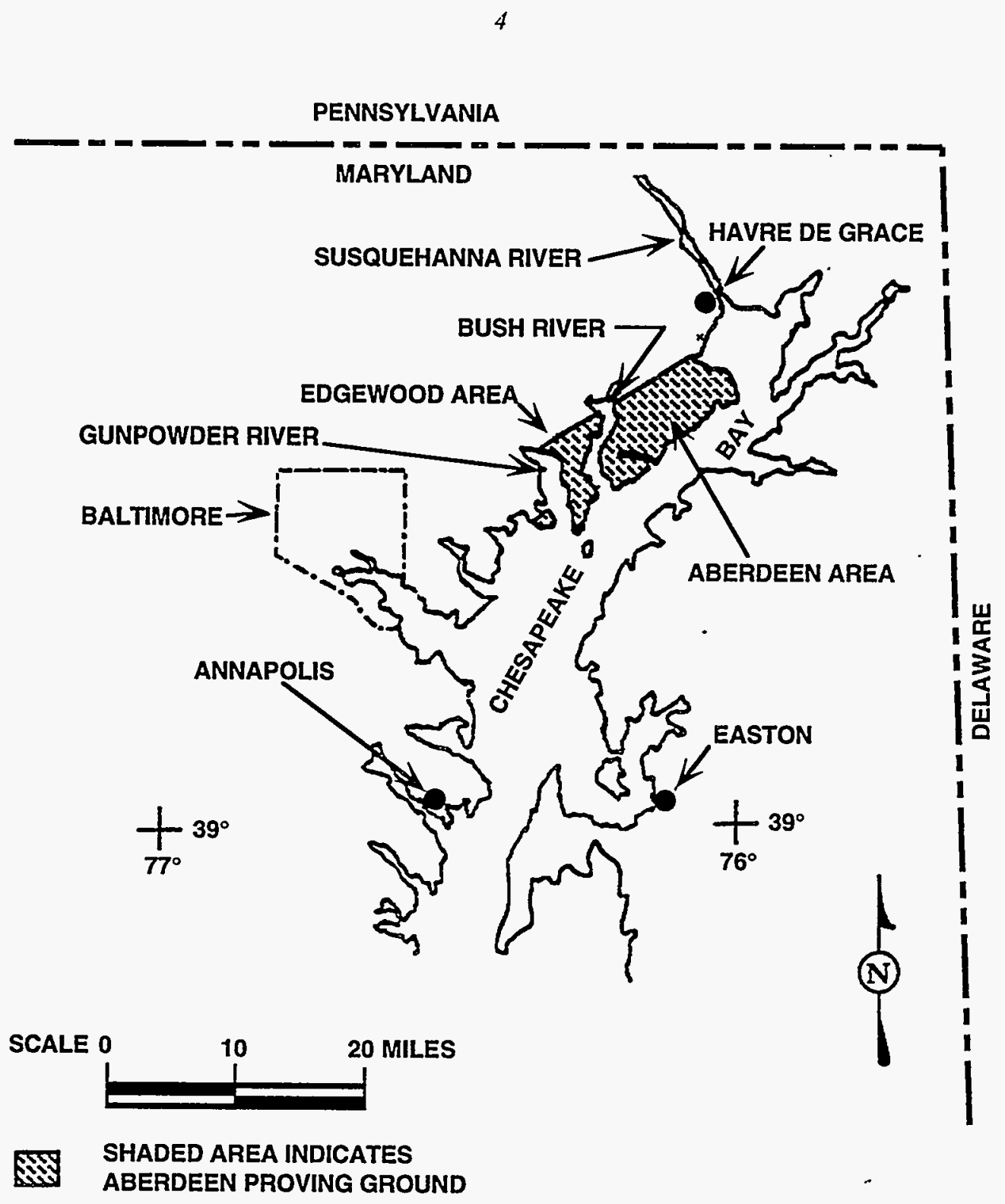

FIGURE 1 Map of Aberdeen Proving Ground Location 


\section{Methodology}

Before the detailed building inspection, ANL personnel made a preliminary site visit to locate the building and obtain building records from APG, identify potential issues to be addressed in the health and safety plan, resolve any access restriction issues, and identify required support services.

Photographs were taken of the building's exterior and interior surfaces during the building inspection in November 1994. The photographs followed a set sequence whenever possible. The exterior was photographed starting on the north side and continuing clockwise around the building; walls were photographed starting in the north or northwest corner of each room and continuing clockwise until reaching the starting point. The ceiling and floor of each room were also photographed.

Detailed descriptions of the methodologies used for the geophysical survey are provided in the appendix to this report. 


\section{Historical Record Search}

Building E2370 (APG designation), originally known as Building 934, is located in the old Toxic Gas Yard (TGY) or the Bush River Area Radioactive Material Disposal Facility (BRRMDF). Both of these are in an area that is presently referred to as the Chemical Agent Storage Yard (CASY) in the Bush River Area of APG's Edgewood Area (Nemeth 1989).

According to historical records (EAI Corporation 1989), Building E2370 was constructed in 1931 and was originally used as a white phosphorus (WP) bulk storage facility or vault. According to Nemeth (1989), in 1960, approximately 717 55-gal drums of adamsite (DM) were buried in sand in the west half of the building. A 1-ft-thick concrete cap was poured over the top of the drums. In 1983, the concrete cap and the drums were removed. From about 1970 through 1980 , the building was used as a radiological waste drum shop. Wastewater from showers used for decontamination was stored in the east open vault until it could be tested for contamination (EAI Corporation 1989).

According to the EAI Corporation report, groundwater and soil samples collected around Building E2370 contained arsenic at levels similar to background levels, except for one sample taken near the southwest corner of the building. The EAI Corporation report suggests that this area was used as a vault filling zone and that a spill might have occurred. Potential contaminants in Building E2370 include the following: adamsite (DM), chloroacetophenone (CN), arsenic compounds, unspecified alpha- and beta-particle-emitting radioisotopes, potassium-40 betaparticle-emitting radioisotope, tritium beta-particle-emitting radioisotope, and cesium-137 betaparticle-emitting radioisotope (EAI Corporation 1989). Many attempts have been made to determine the level of contamination from chemicals stored inside the buildings and the level of radiological contamination, if any. The findings of the chemical analysis are contradictory, depending upon how the analysis was performed (EAI Corporation 1989). Although the results of analysis for radiological contamination were also conflicting, only the vent pipe showed concentrations of beta particle emissions above the regulated permissible levels (EAI Corporation 1989).

The west vault or room 2 was empty at the time of the ANL field investigation. The east vault or room 1 contained water, roofing material, and scrap metal at the time of the ANL field investigation. Frogs were observed in that water.

The floor plan of Building E2370 was developed from measurements taken during the ANL field survey and historical documentation (EAI Corporation 1989). Photographs of the exterior elevations (sides of the building) and photographs of the interior walls, ceiling, and floor of Building E2370 were taken during the field survey in November 1994. 


\section{Building Description}

This section provides a physical description of Building E2370 and the surrounding site as they appeared during the ANL inspection in November 1994. This physical description includes an account of the condition of the exterior walls, roof, interior walls, ceiling, and floor of the building. Evidence of plumbing, heating, electrical connections, and floor drains was observed inside the building during the ANL inspection.

\subsection{Site Description}

\subsubsection{Location}

Building E2370 is located in the CASY of the Bush River Area of APG's Edgewood Area. A gravel road on the east and south sides of Building E2370 intersects 25th Street approximately $800 \mathrm{ft}$ to the south of the building. Bush River Road is approximately $2,100 \mathrm{ft}$ west of Building E2370. As shown in Figure 2, the east corner of the building is approximately $55 \mathrm{ft}$ west of the Bush River.

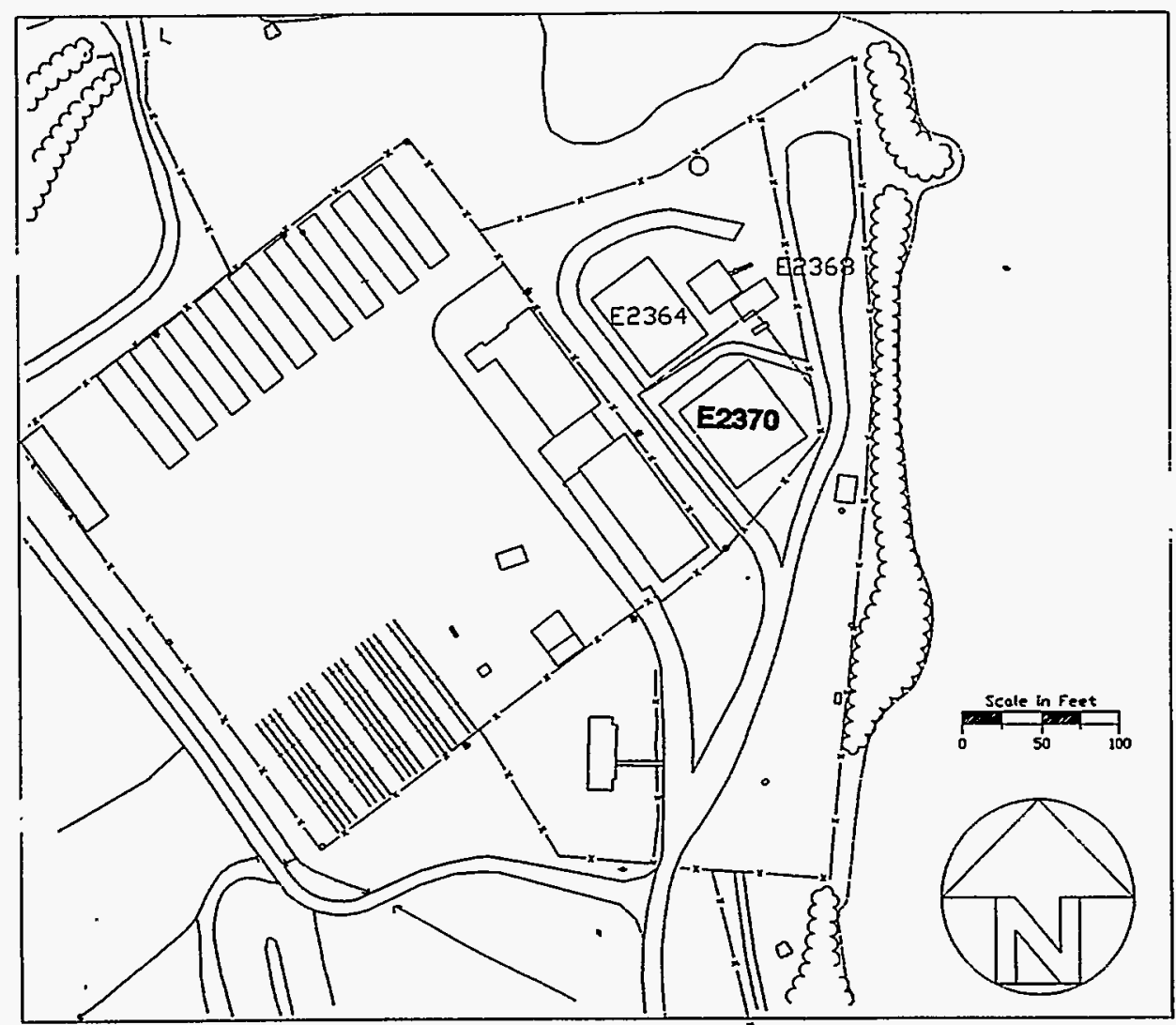

FIGURE 2 Map of Building E2370 Location 


\subsubsection{Proximity to Other Buildings}

Building E2370 is located approximately $30 \mathrm{ft}$ southwest of Building E2368, the liquid waste concentrator facility, and $40 \mathrm{ft}$ south of Building E2364 (Figure 2).

\subsubsection{Building Structure}

Building E2370 is a waterproof storage vault with a metal corrugated roof; the structure is open to the exterior on all sides. The roof is supported by a steel frame structure on concrete columns. The exterior walls of the building, which extend from the floor slab to approximately $4 \mathrm{ft}$ above the ground, are 12-in.-thick reinforced concrete. The interior wall is 24-in.-thick reinforced concrete. There are no windows or doors in the building. Figure 3 presents a floor plan of the building, as surveyed at the time of the inspection. Figure 4 provides photographs of the building exterior.

\subsubsection{Exterior Dimensions}

The exterior horizontal dimensions of Building E2370 (main portion) are $62 \mathrm{ft}$ horizontally along the west wall by $54 \mathrm{ft}$ horizontally along the north wall. The roof of the building measures $9 \mathrm{ft}$ in the middle and $4 \mathrm{ft}$ at the ends, above the top of the north wall (Figure 4).

\subsubsection{Topography}

The area directly surrounding Building E2370 is flat. The ground slopes downward away from the building to the east and south. A pile of crushed concrete was observed east of the building.

\subsubsection{Vegetation in the Immediate Vicinity}

The area surrounding Building E2370 on the north, south, and west sides consists primarily of gravel. The area to the east is covered by scattered weeds and lawn, with no trees or shrubs in the area. 


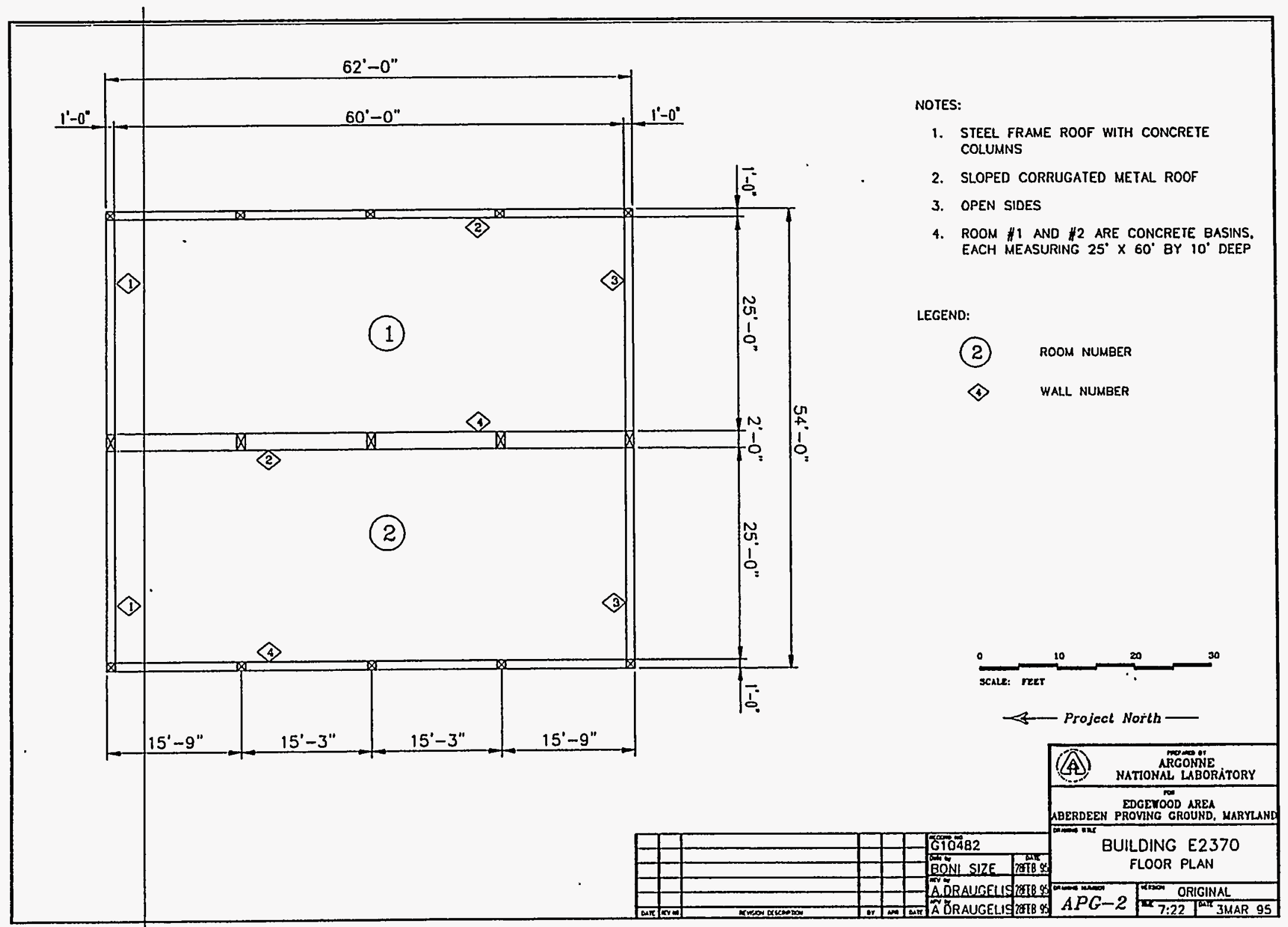

FIGURE 3 Building E2370 Floor Plan 


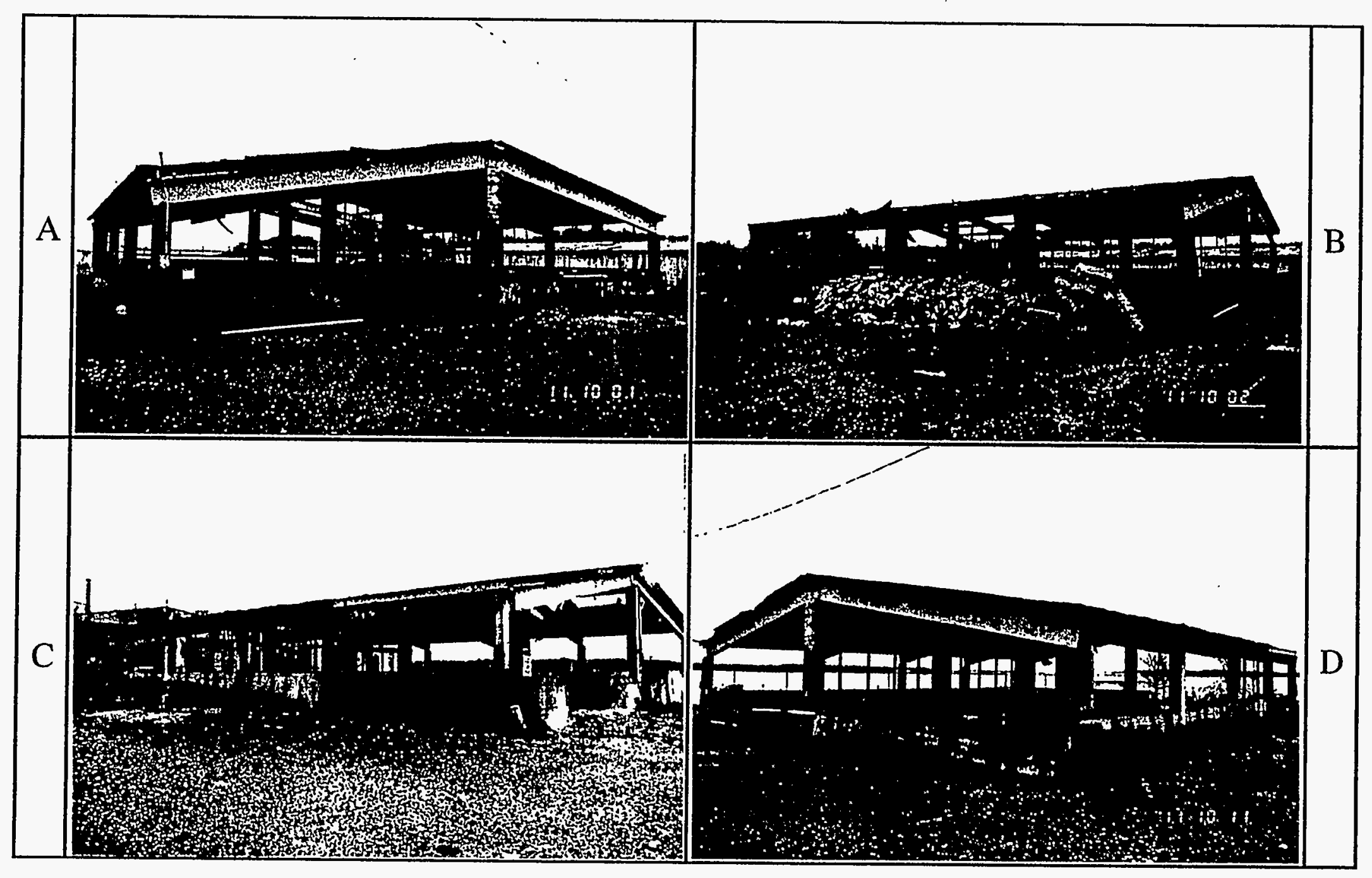

\begin{tabular}{|l|l|}
\hline A & East \& North Elevation \\
\hline C & West \& South Elevation \\
\hline
\end{tabular}

Eust \& North Elevation

North \& West Elcvation

FIGURE 4 Photographs of Building E2370 Exterior 


\subsubsection{External Aboveground Structures or Equipment}

Two monitoring wells were observed, one on the north and one on the west side of the building.

\subsubsection{Connections with Adjacent Buildings}

None.

\subsubsection{Underground Structures}

None.

\subsubsection{Surface Drainage System}

None.

\subsubsection{Utility Access Points}

None.

\subsubsection{Exterior Piping}

See Section 4.1.7 above.

\subsubsection{Nearby Roads and Sidewalks}

A gravel road runs north to south approximately $15 \mathrm{ft}$ from the east and south sides of Building E2370. Approximately $800 \mathrm{ft}$ to the south is 25 th Street.

\subsubsection{Other}

Frogs were observed in the water in the eastern vault (room 1). 


\subsection{North Exterior Elevation}

\subsubsection{Dimensions}

The north exterior elevation of the structure of Building E2370 shown in Figure 4 measures $54 \mathrm{ft}$ long and approximately $9 \mathrm{ft}$ high in the middle and $4 \mathrm{ft} \mathrm{high}$ at each end from the top of the wall to the roof line (Figure 3).

\subsubsection{Construction Materials}

The exterior wall of Building E2370 consists of 12 in. of poured reinforced concrete. Structural concrete columns, $26 \mathrm{ft} 6$ in. on center, support an I beam that is part of the structural steel frame for the roof.

\subsubsection{Doors and Windows}

None.

\subsubsection{Piping}

- None.

\subsubsection{Utility Connections}

Electrical conduit extends from a blue metal box on the wall to the roof and along the length of the I beam.

\subsubsection{External Equipment or Structures}

A monitoring well is located north of Building E2370. Three 55-gal steel drums with unknown contents were observed adjacent to the monitoring well. 


\subsubsection{Vegetation} E2364.

An area of gravel and patches of weeds/grass are located between Buildings E2370 and

\subsubsection{Overall Condition}

Because of a lack of maintenance, the north elevation shows signs of deterioration and weathering. Oxidized metals and cracks in the concrete were observed at the time of this investigation.

\subsection{East Exterior Elevation}

\subsubsection{Dimensions}

The east exterior elevation of Building E2370 measures $62 \mathrm{ft}$. long and approximately $4 \mathrm{ft}$ high from the top of the wall to the roof (Figure 3).

\subsubsection{Construction Materials}

The exterior wall of Building E2370 consists of 12 in. of poured reinforced concrete. Structural concrete columns, $15 \mathrm{ft} 3 \mathrm{in}$. on center, support I beams that are part of the structural steel frame for the roof.

\subsubsection{Doors and Windows}

None.

\subsubsection{Piping}

None. 


\subsubsection{Utility Connections}

None.

\subsubsection{External Equipment or Structures}

A pile of broken pieces of concrete was observed along this elevation.

\subsubsection{Vegetation}

Weeds and grasses are located near the east elevation.

\subsubsection{Overall Condition}

Because of a lack of maintenance, the east elevation shows signs of deterioration and weathering. Oxidized metals and cracks in the concrete were observed at the time of the investigation.

\subsection{South Exterior Elevation}

\subsubsection{Dimensions}

The south exterior elevation of Building E2370 measures $54 \mathrm{ft}$ long and approximately $9 \mathrm{ft}$ high in the middle and $4 \mathrm{ft}$ high at each end from the top of the wall to the roof line (Figure 3).

\subsubsection{Construction Materials}

The exterior wall of Building E2370 consists of 12 in. of poured reinforced concrete. Structural concrete columns, $26 \mathrm{ft} 6 \mathrm{in}$. on center, support I beams that are part of the structural steel frame for the roof. 


\subsubsection{Doors and Windows}

None.

\subsubsection{Piping}

The south exterior elevation of Building E2370 contains one pipe extending from approximately $4 \mathrm{ft}$ from the ground and $1 \mathrm{ft} 6$ in. east of the center concrete column.

\subsubsection{Utility Connections}

Two electrical conduits extend from a rusted utility box to the roof along the center concrete column.

\subsubsection{External Equipment or Structures}

None.

\subsubsection{Vegetation}

Weeds and grasses are growing near the south elevation of Building E2370.

\subsubsection{Overall Condition}

Because of a lack of maintenance, the south elevation shows signs of deterioration and weathering. Oxidized metals and pieces of the concrete wall that had been removed and fallen to the ground were observed at the time of this investigation. 


\subsection{West Exterior Elevation}

\subsubsection{Dimensions}

The west exterior elevation of Building E2370 measures $62 \mathrm{ft}$ long and approximately $4 \mathrm{ft} \mathrm{high} \mathrm{from} \mathrm{the} \mathrm{top} \mathrm{of} \mathrm{the} \mathrm{wall} \mathrm{to} \mathrm{the} \mathrm{roof} \mathrm{(Figure} 3$ ).

\subsubsection{Construction Materials}

The exterior wall of Building E2370 consists of 12 in. of poured reinforced concrete. Structural concrete columns, $15 \mathrm{ft} 3 \mathrm{in}$. on center, support I beams that are part of the structural steel frame for the roof.

\subsubsection{Doors and Windows}

None.

\subsubsection{Piping}

None.

\subsubsection{Utility Connections}

None.

\subsubsection{External Equipment or Structures}

A monitoring well is located west of Building E2370.

\subsubsection{Vegetation}

West of Building E2370 is an expansive area of gravel with patches of weeds. 


\subsubsection{Overall Condition}

Because of a lack of maintenance, the building shows signs of deterioration and weathering. Oxidized metals and cracks in the concrete wall were observed at the time of the investigation.

\subsection{Roof}

\subsubsection{Type and Dimensions}

Building E2370 has a sloping, corrugated, sheet metal roof measuring $62 \mathrm{ft}$ by $54 \mathrm{ft}$ (Figures 3 and 4).

\subsubsection{Height}

The gable roof is approximately $13 \mathrm{ft}$ high in the middle of the building and slopes downward to a height of $8 \mathrm{ft}$ at the east and west walls.

\subsubsection{Surface Materials}

The building of E2370 has a sloping, corrugated, sheét metal roof.

\subsubsection{Support System}

The roof of Building E2370 is supported by a structural steel framework. The concrete columns that support the steel roof joists are placed $15 \mathrm{ft} 3 \mathrm{in}$. on center and oriented in a northsouth direction.

\subsubsection{Condition}

The roof of Building E2370 has been removed over the southern portion of room 1 and half of the southern portion of room 2. Roof sections are divided into four quarters by the concrete supports. 


\subsubsection{Equipment Located on the Roof}

None.

\subsubsection{Chimneys, Roof Vents, or Vent Stacks}

None.

\subsubsection{Piping}

None.

\subsection{Interior Floor Plan}

\subsubsection{Room Numbers and Dimensions}

Building E2370 is a single-story, two-room, vaulted building with interior building dimensions of $60 \mathrm{ft}$ long by $52 \mathrm{ft}$ wide (Figure 3 ).

\subsubsection{Walls}

The walls of the rooms that coincide with the exterior walls of the building are 12-in.-thick reinforced concrete. These 10-ft-long walls extend from the floor of the building to the approximately $4 \mathrm{ft}$ above the ground surface (Figures 5 and 6).

\subsubsection{Floor}

The concrete floor in Building E2370 is in good condition.

\subsubsection{Floor Penetrations}

The building contains no floor drains, sumps, or sinks (EAI Corporation 1989). An 8-in.-diameter air vent pipe is located in room 2 along wall 3. 


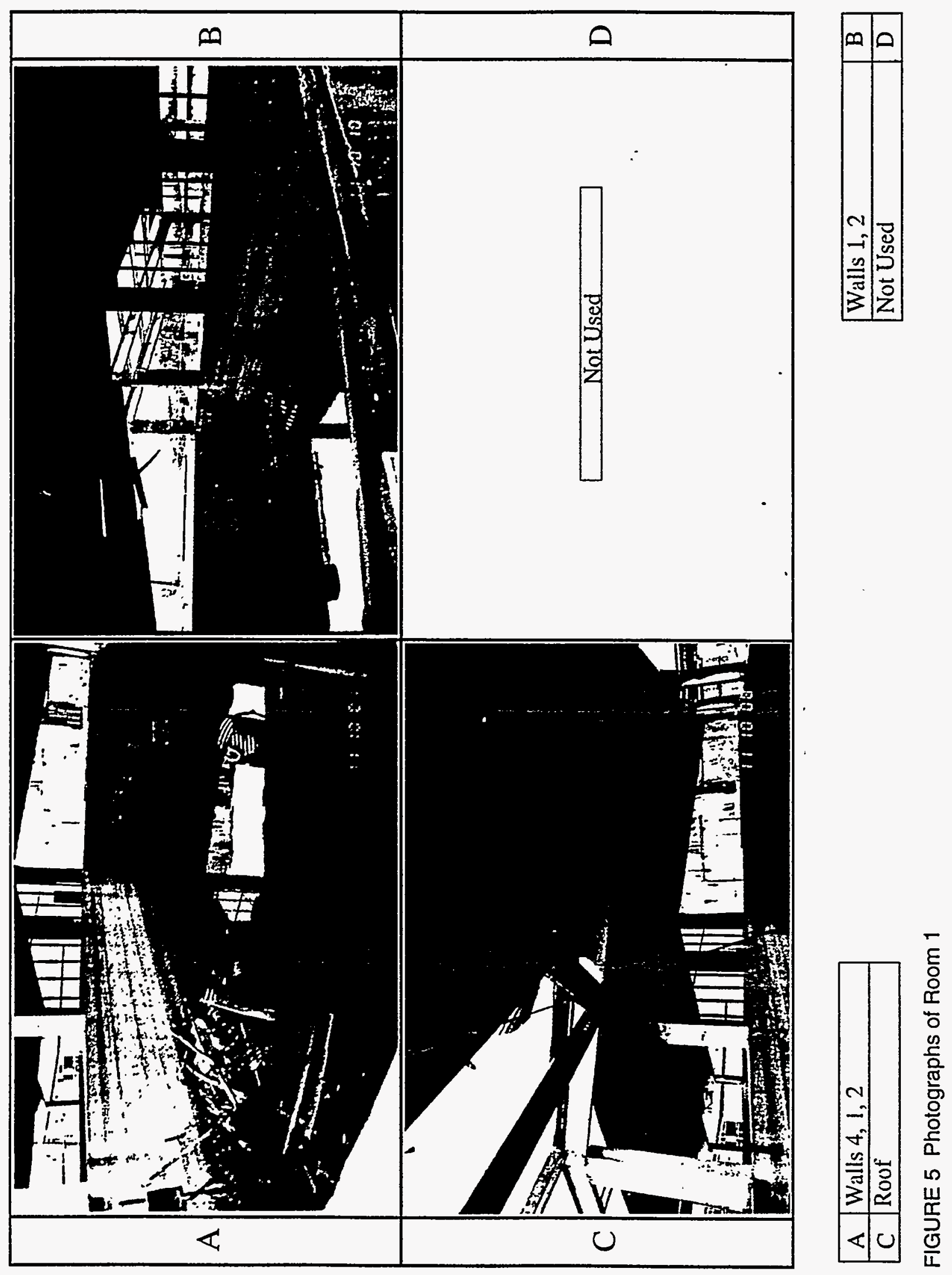



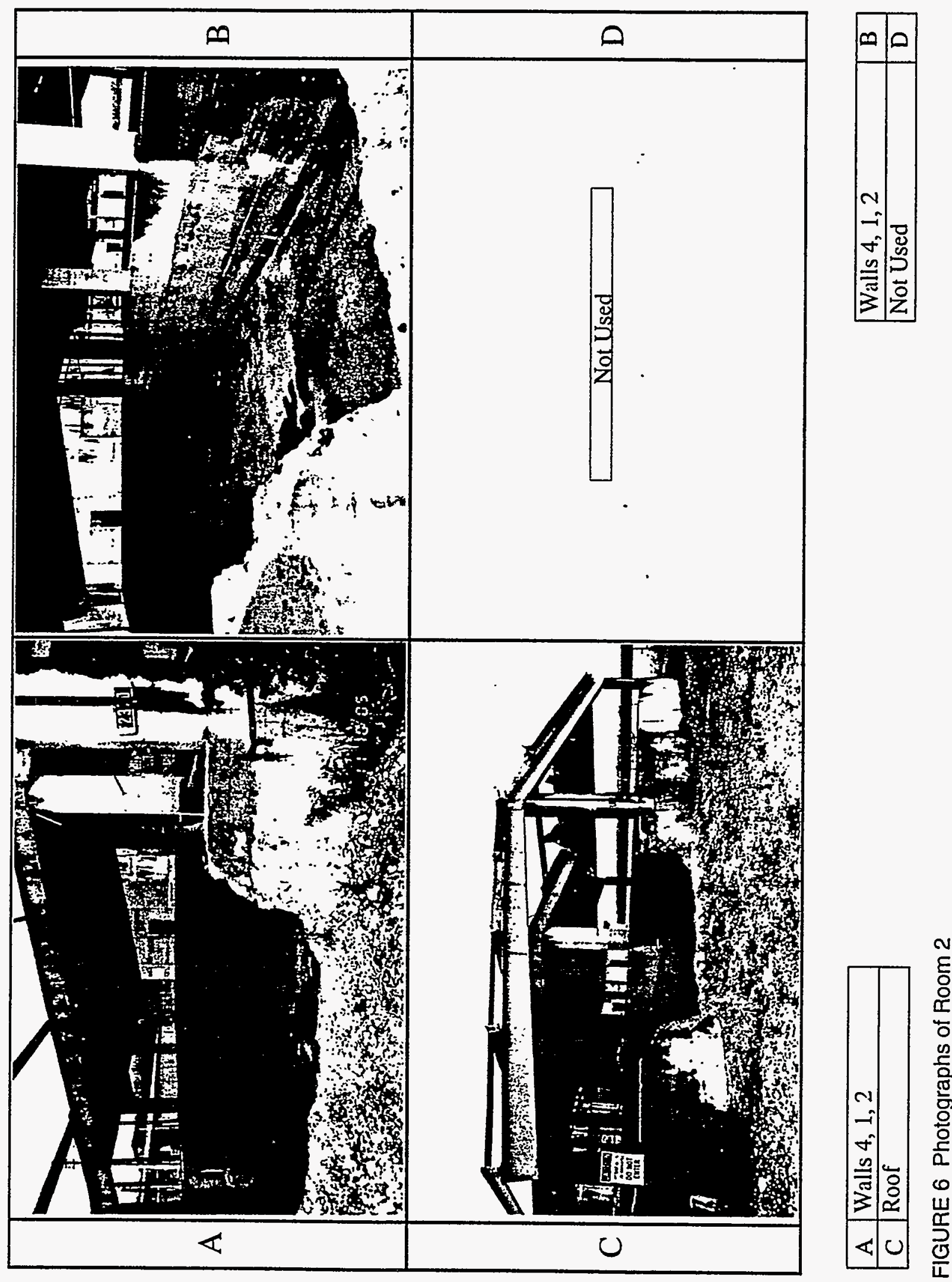


\subsubsection{Interior Partitions}

Building E2370 is a two-room structure with interior partitions as shown in the floor plan (Figure 3). The interior partitions/walls separating rooms 1 and 2 consist of 2 -ft-thick, reinforced, poured concrete.

\subsubsection{Equipment or Supplies}

None.

\subsection{Room 1}

\subsubsection{Walls}

Walls 1,2 , and 3 are constructed of 1 -ft-thick reinforced concrete. Wall 4 is constructed of 2-ft-thick reinforced concrete.

\subsubsection{Finish Materials}

The interior walls of the room are unpainted concrete.

\subsubsection{Piping}

None.

4.8.4 Equipment

None.

\subsubsection{Doors and Windows}

None. 


\subsubsection{Ceiling and Floor}

The floor consists of reinforced concrete that is $10 \mathrm{ft}$ deep from the top of the concrete wall. Standing water this room contains sections of the roof and other metallic objects. The ceiling, also the underside of the roof, is made of corrugated sheet metal (Figure 5).

\subsection{Room 2}

\subsubsection{Walls}

Walls 1,3 , and 4 are constructed of 1 -ft-thick reinforced concrete. Wall 2 is constructed of 2-ft-thick reinforced concrete.

\subsubsection{Finish Materials}

The interior walls of the room are unpainted concrete.

\subsubsection{Piping}

A 8-in.-diameter air vent pipe is located in room 2 along wall 3.

\subsubsection{Equipment}

None.

\subsubsection{Doors and Windows}

None.

\subsubsection{Ceiling and Floor}

The floor in room 2 consists of reinforced concrete that is $10 \mathrm{ft}$ deep from the top of the concrete wall. The ceiling, also the underside of the roof, is corrugated sheet metal (Figure 6). 


\section{Geophysical Investigation}

A geophysical survey was conducted by ANL around Building E2370 by using several nonintrusive geophysical survey methods. A copy of the geophysical suryey report is presented in the appendix.

Results from the geophysical surveys reveal the following:

- Geophysical observations within the primary geophysical survey area reveal no evidence of buried pipes, trenches, or sewer lines.

- Northeast of Building E2370, between the two fences, ANL detected an electromagnetic field (EMF) lineation caused that could be caused by a buried metal pipe. Magnetic and GPR anomalies were also observed nearby. This lineation may extend beneath the fence south of Building E2370, although possible interference from the metals in the fence prevents a definite interpretation.

- Small-diameter magnetic and EMF anomalies correlated throughout much of the survey area. Other magnetic anomalies detected did not correlate with EM-61 observations. The source(s) of these anomalies is unknown.

- A strong magnetic anomaly correlates with a broad, low-amplitude, EMF anomaly detected near a point $73 \mathrm{ft}$ east of the east elevation. A strong EMF anomaly was also observed between a point $85 \mathrm{ft}$ east of the east elevation and $2 \mathrm{ft}$ north of the north elevation and a point $82 \mathrm{ft}$ east of the east elevation and $21 \mathrm{ft}$ north of the north elevation. The cause(s) of these anomalies is also unknown. 


\section{Air Monitoring}

No information on air monitoring associated with Building E2370 is available. 


\section{Underground Storage Tanks}

No information on underground storage tanks associated with Building E2370 is available. 


\section{Conciusions}

On the basis of the information collected and reviewed by ANL for Building E2370, it is the authors' judgment that the anomalies detected during the geophysical survey in the vicinity of Building E2370 should be further investigated and evaluated. 


\section{References}

Brubaker, K.L., J.M. Dougherty, and L.D. McGinnis, 1994, Initial Building Investigation at Aberdeen Proving Ground, Maryland: Objectives and Methodology, ANL/ESD/TM-61, Argonne National Laboratory, Argonne, Ill.

EAI Corporation, 1989, Historical Records Search and Site Survey of the Edgewood Area Building - Final Report, prepared for U.S. Army Chemical Research, Development, and Engineering Center, Aberdeen Proving Ground, Maryland, under contract no. DAAIS-87-D0021.

Nemeth, G., 1989, RCRA Facility Assessment Report, Edgewood Area, Aberdeen Proving Ground, Maryland, unnumbered report prepared for Aberdeen Proving Ground, Maryland. 
Appendix:

Interim Progress Report -

Environmental Geophysics:

Building E2370 Decommissioning,

Aberdeen Proving Ground 


\section{Interim Progress Report - \\ Environmental Geophysics: \\ Building E2370 Decommissioning, \\ Aberdeen Proving Ground}

\section{Prepared by}

J.E. Stefanov, G.J. Kuecher, M.A. Glennon, M.D. Thompson, C.R. Daudt, and M.A. Benson

Center for Environmental Restoration Systems

Energy Systems Division

Argonne National Laboratory

9700 South Cass Avenue

Argonne, IL 60439

August 1995

Sponsored by

U.S. Army

Aberdeen Proving Ground, Maryland 


\section{Preface}

This report is one of a series on environmental geophysical studies around perimeters of buildings in the Edgewood Area of Aberdeen Proving Ground. The series was initiated in 1991 at Building E5032, where techniques were evaluated and a design for the surveys was established. Studies continued in 1992 and 1993, when surveys of Buildings.E5190, E5282, E5375, E5440, E5476, E5481, E5485, E5487, E5489, E5974, E5978, and the Building E103 Dump were completed. In 1994, geophysical surveys were completed around Buildings E1489, E2370, E3162, E3163, E3180, E3236, E3613, E3640, E6891, and E7995, and Building E5032 was resurveyed; newer, continuously recording equipment was used in all 1994 surveys. Deeper insight into the magnetic, electrical, and radar imagery characteristics of the Canal Creek and Kings Creek Areas has been gained from the completion of each geophysical survey. Subsequent improvements in survey design and data acquisition, processing, and interpretation have been realized at more recent sites, including Building E2370. 


\section{Contents}

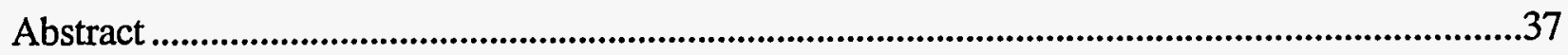

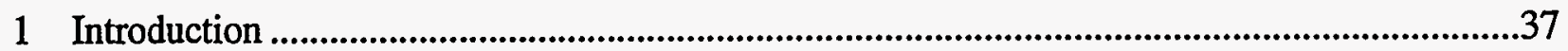

1.1 History of Building E2370 ................................................................................................38

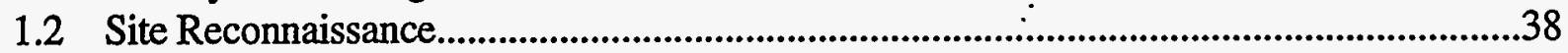

1.3 Geology and Physiographic Setting...............................................................................40

1.4 Surveys........................................................................................................................40

1.5 Survey Grid and Locations of Observations.....................................................................40

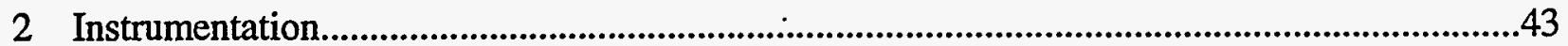

2.1 Magnetic Gradiometer and Cable Locator ..........................................................................4

2.2 Total-Field Magnetics Meter G-822L ............................................................................4

2.3 Time-Domain Millivolt Meter EM-61 ............................................................................44

2.4 Ground-Penetrating-Radar System......................................................................................44

3 Geophysical Measurements and Surveys .................................................................................45

3.1 Total-Field Magnetics Measurements..............................................................................45

3.2 Induced-EMF Measurements............................................................................................4

3.3 Ground-Penetrating-Radar Measurements .........................................................................49

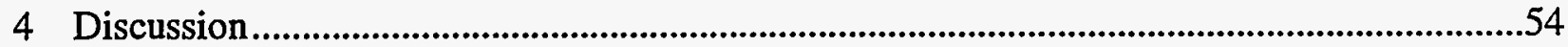

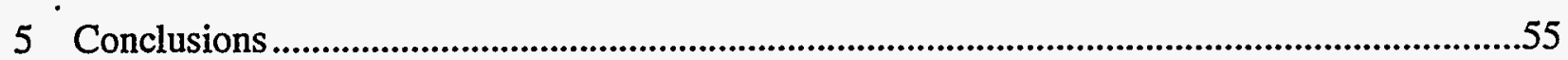

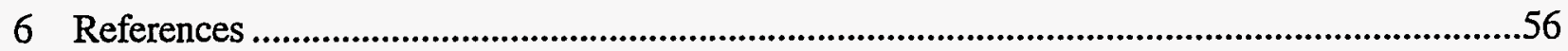

Attachment: Ground-Penetrating-Radar Line Coordinates for Building E2370 ..............................59

\section{Table}

1. Location and Description of Geophysical Anomalies Detected Near Building E2370. 


\section{Figures}

1. General Location Map of the Bush River Peninsula, Aberdeen Proving Ground, Md.

2. Detailed Site Map of the Building E2370 Site.

3. Map of the Total Magnetic Field Anomalies at Building E2370 (measured by using a Geometrics G-822L cesium-vapor magnetometer).

4. Map of the EMF Anomalies at Building E2370 (measured by using a Geonics EM-61 instrument). 48

5. Locations of Ground-Penetrating-Radar Profiles....................................... 50

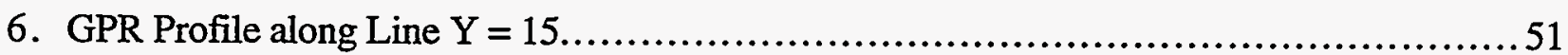

7. GPR Profile between the Two Fences........................................... 52 


\title{
Interim Progress Report - \\ Environmental Geophysics: \\ Building E2370 Decommissioning, Aberdeen Proving Ground
}

\author{
by \\ J.E. Stefanov, G.J. Kuecher, M.A. Glennon, \\ M.D. Thompson, C.R. Daudt, and M.A. Benson
}

\begin{abstract}
Noninvasive geophysical techniques were used to survey Building E2370, a potentially contaminated site in the Bush River Peninsula Area of Aberdeen Proving Ground. Magnetic and induced electromagnetic field (EMF) techniques, and ground-penetrating radar (GPR) were used as part of a sampling and monitoring program prior to decommissioning of the building. Geophysical observations within the fenced area peripheral to Building E2370 show no evidence of buried pipes, trenches, or sewer lines. Outside of the fence, EMF, magnetic, and GPR observations suggest that a metal drainage pipe extends from the southeast corner of the fence to the Bush River. Magnetic and EMF anomalies are associated with the building and monitoring wells WBR-90, WBR-91, and WBR-92. Unidentified sources produce magnetic and EMF anomalies northwest and southeast of the building. Point-source magnetic anomalies scattered throughout the survey area do not correlate with other data. GPR transects offer poor resolution in this area. Magnetic and EMF anomalies are centered at $\mathrm{X}=160, \mathrm{Y}=100$.
\end{abstract}

\section{Introduction}

Aberdeen Proving Ground (APG), in the state of Maryland, is managing a comprehensive Installation Restoration Program involving more than 360 solid-waste managing units contained within 13 study areas. The Edgewood Area of Aberdeen Proving Ground appears on the National Priority List under the Comprehensive Environmental Response, Compensation, and Liability Act. Therefore, APG has entered into an Interagency Agreement with the U.S. Environmental Protection Agency to address the listed areas.

A report prepared by the EAI Corporation (1989) included a list of 29 potentially contaminated buildings in the Edgewood Area of Aberdeen Proving Ground. The buildings have been abandoned and operations have ceased, but processing equipment, incinerators, sumps, drains, ventilation systems, and underground storage tanks remain. These appurtenances may contain liquid, solid, or vapor contaminants of unknown nature. Sixteen of the buildings contain known contaminants, nine buildings contain unknown contaminants, and four of the buildings are potentially clean. The EAI report recommended that a sampling and monitoring program be 
established to verify contamination levels in and around each building. Most of the effort thus far has been in the western Canal Creek Area and the Kings Creek Area.

Aberdeen Proving Ground is proceeding with a program to decommission the buildings, which will eliminate the actual or potential release of contaminants into the environment. Argonne National Laboratory (ANL) has been assigned the task of developing a plan and scope of work for the proposed decommissioning. Argonne has determined that the first step in this decommissioning process, where it is technically feasible, should be a noninvasive geophysical survey around building exteriors.

\subsection{History of Building E2370}

Building E2370, originally known as Building 934, is located in the old Toxic Gas Yard (TGY) in the Bush River Area (see Figure 1) (Nemeth 1989). According to historical records (EAI Corporation 1989), Building E2370 was constructed in 1931 and was originally used as a white phosphorus (WP) bulk storage facility or vault. According to the Nemeth report, in 1960 approximately 717 fifty-five-gallon drums of Adamsite (DM) were buried in sand in the west half of the building. A 1-ft concrete cap was poured over the top of the drums. In 1983 the drums were removed. From about 1970 through 1980, the building was used as a radiological workdrum shop. Wastewater from showers used for decontamination was held in the east open vault until tests for contamination could be performed (EAI Corporation 1989).

According to the EAI report, groundwater and soil samples taken in the area of the building have arsenic at levels similar to background levels, except for one sample taken near the southwest corner of the building. The EAI report suggests that this area was used as a vault-filling zone and that a spill might have occurred. Potential contaminants at Building E2370 are: Adamsite (DM), chloroacetophenone (CN), arsenic compounds, unspecified alpha- and betaparticle-emitting radioisotopes, potassium- 40 beta-particle-emitting radioisotope, tritium betaparticle-emitting radioisotope, and cesium-137 beta-particle-emitting radioisotope (EAI Corporation 1989). The west vault (or room 01) was empty at the time of the ANL field investigation. The east vault (or room 02) contained water, roofing material, and scarp metal at the time of the ANL field investigation.

\subsection{Site Reconnaissance}

The geophysical survey program design for Building E2370 was based on similar studies conducted by ANL personnel at APG since 1991 (McGinnis and Miller 1991; L.D. McGinnis et al. 1992a,b, 1994, 1995; M.G. McGinnis et al. 1992a,b; Miller et al. 1992a,b; Thompson et al. 1992a,b, 1994, 1995; Benson et al. 1995; Daudt et al. 1995). The initial evaluation was enhanced by a November 1991 site visit and by inspection of aerial photos available to Argonne personnel. 

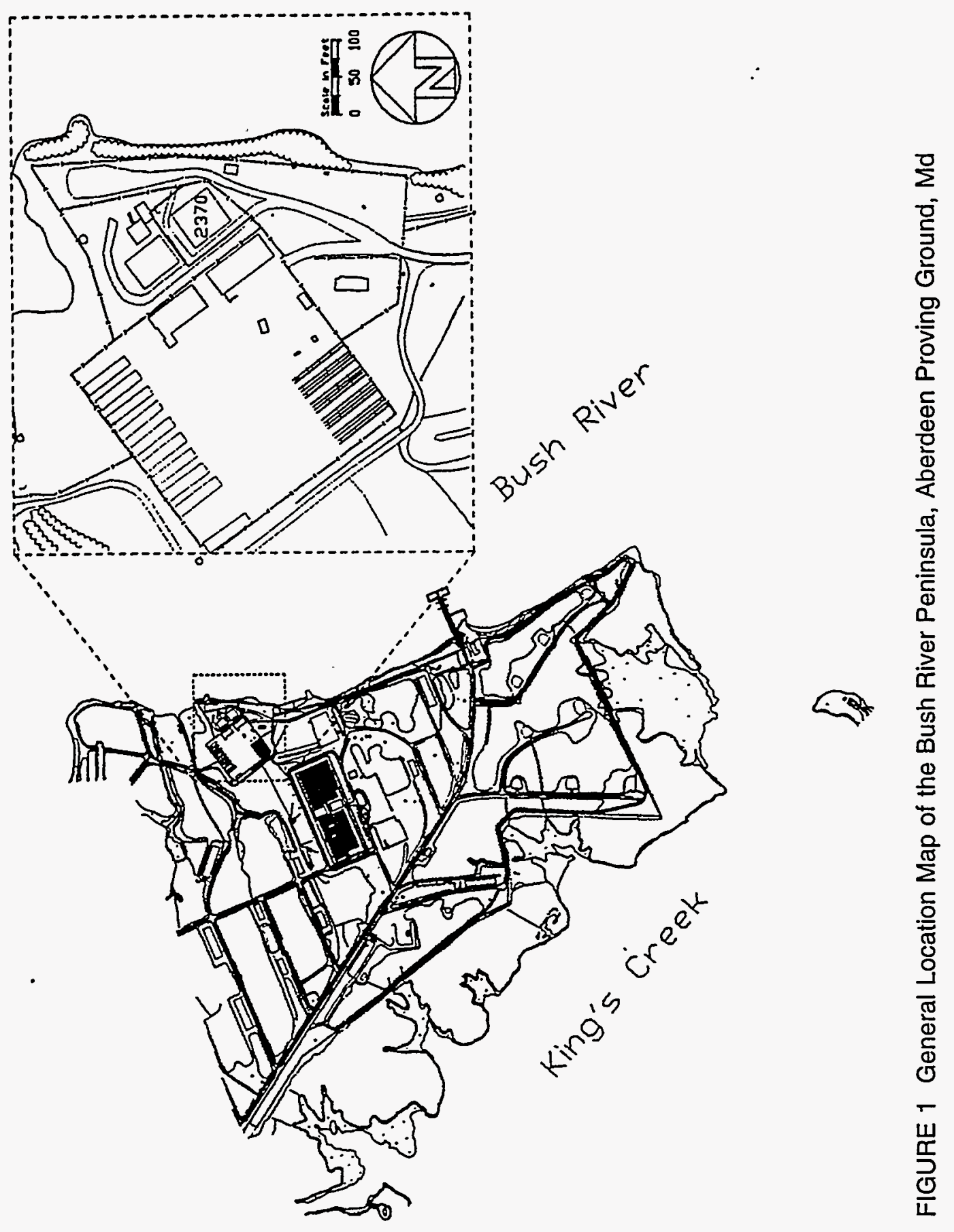
Building E2370 is located along the western shore of the Bush River and is approximately $55 \mathrm{ft}$ from the river (Figure 2). Buildings E2364 and E2368 are located within $30 \mathrm{ft}$ of Building E2370 to the north and northeast, respectively. The area surrounding Building E2370 is flat, and the ground surface is composed primarily of gravel. A pile of crushed concrete is immediately east of the building, and some scattered weeds and grass were present during the geophysical survey. There are three monitoring wells around the building (WBR-90, -91, and -92). The lithologic logs for these wells are not available, and no other wells are in close proximity to the survey area.

In planning the geophysical survey, subsurface characteristics at the site were considered in addition to the surface conditions. Surficial sediments consist of nonmagnetic estuarine sands, silts, and clays that have electrical properties which vary both horizontally and vertically, because of either natural conditions or excavation and building effects. Such sources as iron-rich magnetized objects, nonmagnetic objects, and subsurface channels containing contaminants may be present in the subsurface.

\subsection{Geology and Physiographic Setting}

The Bush River Peninsula is contained in topographically low and flat terrain of the Coastal Plain physiographic province. The Bush River Peninsula is underlain by alluvial and estuarine sands, silts, and clays. A thin veneer of sediments of the Talbot Formation of Pleistocene age overlies unconsolidated sediments of the Potomac Group of Cretaceous' age (Oliveros and Gernhardt 1989).

\subsection{Surveys}

Geophysical data were acquired during five days of - field operations during December 1994. On-site personal computers (both notebook and desktop), interactive software, and field equipment designed specifically for APG building studies were used to expedite data acquisition and processing. Surveys were conducted to measure total-field magnetics, inducedelectromagnetic-field (EMF), and ground-penetrating-radar (GPR) profiles. Electrical conductivity measurements were not taken around Building E2370 because of the close proximity and abundance of aboveground structures (metal fences, posts, etc.) that interfere with conductivity measurements.

\subsection{Survey Grid and Locations of Observations}

Prior to geophysical surveying, wooden stakes were placed at the site corners to mark the area to be surveyed. A grid was positioned so that the southwestern grid corner was located at coordinates $X=0, Y=0$, and its axes were parallel to the edges of the building. Positive $X$ and $Y$ coordinates were measured approximately east and northwest of the starting coordinates (Figure 2). For convenience, a location of $X=15, Y=100$ will be represented as $(15,100)$. Within the fenced area, physical properties of the subsurface were measured by the three survey techniques along transects parallel to the $\mathrm{X}$ and $\mathrm{Y}$ axes. 


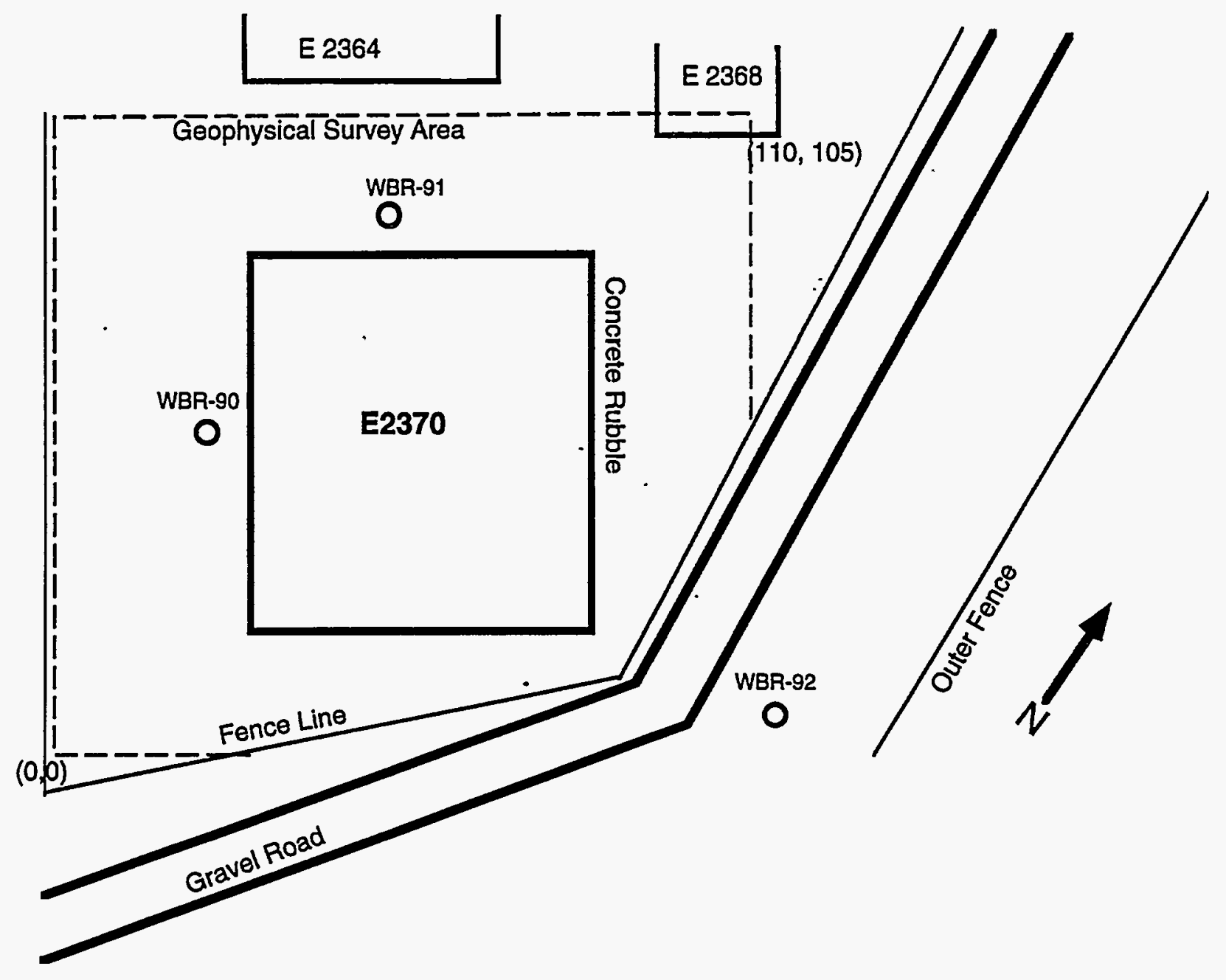

FIGURE 2 Detailed Site Map of the Building E2370 Site 
Immediately east of the fenced area, transects were run between the fence and the shoreline of the Bush River (Figure 2). Magnetometer transects were spaced approximately $10 \mathrm{ft}$ apart, EMF transects were $5 \mathrm{ft}$ apart, and GPR transects were at least $10 \mathrm{ft}$ apart. These profiles were not tied to the profiles inside the fenced area because the lines between the fences were not initially planned as part of the survey. It was decided to run transects between the building and Bush River shoreline to check for the existence of drainlines which could have potentially transported contaminants from Building E2370 into the Bush River. Positions of anomalies outside of the geophysical survey area are probably accurate to within $20 \mathrm{ft}$. 


\section{Instrumentation}

\subsection{Magnetic Gradiometer and Cable Locator}

The Schonstedt MAC-51B magnetic gradiometer and cable locator is a dual-mode instrument designed for detecting shallow-buried iron and steel objects and tracing underground cables and pipes. The system consists of a transmitter and a dual-function receiver designed to detect anomalous magnetic gradients. The MAC-51B is an audio device used only for rapid detection of magnetic materials for further analysis with complementary instrumentation.

Maps or models are not constructed from observations made with this instrument because the MAC-51B is not a calibrated system and it does not have digital data recording. Anomalies are identified by changes in sound amplitude and frequency. Any anomalies detected with the MAC-51B are marked on the ground surface prior to the initiation of other surveys. If the anomalies detected with the MAC-51B cannot be verified with the magnetometer (see Section 2.2), the anomaly is assumed to be insignificant.

Surveying with the MAC-51B in its receiver mode is the first geophysical operation following establishment of survey limits. A qualitative description of the site, with $100 \%$ ground coverage, is achieved by using the gradiometer, whereas the results obtained with other techniques, although more quantitative, are spatially limited to single-point, survey-grid observations or to continuous readings along spaced profiles.

\subsection{Total-Field Magnetics Meter G-822L}

Magnetometer surveys are used for identifying such ferromagnetic objects as tanks, drums, drain pipes, water lines, and small ferrous objects. An EG\&G Geometrics G-822L cesium-vapor magnetometer was used to measure the total magnetic field around Building E1489. The G-822L was operated in a continuous-recording mode and acquired a magnetic measurement at intervals of approximately one-third of a foot.

Because of the dipolar field, a magnetic anomaly due to a source having a simple shape exhibits a characteristic signature consisting of a positive magnetic peak and at least one negative magnetic trough. If a symmetrically shaped body of iron-rich waste is buried in the northern hemisphere and becomes magnetized in the earth's field, a large positive anomaly with a weak negative offset to the north will occur. The horizontal distance between the paired peak and trough is proportional to the depth of burial, the size, and the shape of the source, whereas, the amplitude of the anomaly is inversely proportional to the square of the depth of burial. Metallic debris at, or just below, the ground surface produces strong, closely spaced, magnetic peaks and troughs separated by high gradient areas.

When using the G-822L magnetometer, the sign of magnetic anomalies must be viewed with extreme caution, because in a region of high gradients, the magnetometer becomes untuned and provides zero readings. Contouring software for the G-822L has been designed to bridge the zero gap with mean values taken from the last readable data along the profile. Thus, because of the bipolarity of magnetic anomalies and the variability of gradients, it is possible for an isolated 
anomaly or a lineament to change from a positive to a negative feature along the trend. For the purpose of this study, the polarity of the anomaly is unimportant. The absolute strength of the magnetic anomaly and whether the anomaly appears as a "point" source or as a linear feature are more important to the geophysical interpretation.

\subsection{Time-Domain Millivolt Meter EM-61}

EMF data were obtained in millivolts with a Geonics EM-61, a portable, time-domain, electrical induction instrument that transmits an electrical pulse into the ground and measures secondary EMFs caused by metallic objects beneath the instrument. As a consequence of its coil arrangement, the EM-61 is relatively insensitive to surface interference and is more sensitive to deeply buried metallic targets. Data are recorded on three channels: responses from an upper coil, a lower coil, and a coil difference.

Data were collected at a rate of three readings per second and were stored on the OMNI 720 data logger. Internal software permitted downloading data directly into an on-site computer. Contouring of data in millivolts $(\mathrm{mV})$ was incorporated into the field acquisition procedure, so that daily map outputs were available for observation and interpretation. Inspection of the data sets acquired at Building E2370 and at other APG sites surveyed by Argonne personnel indicates that the measurements obtained from the lower coil are sufficient to identify buried metallic sources within the gridded area.

\subsection{Ground-Penetrating-Radar System}

Ground-penetrating-radar surveying and data processing were accomplished by using Geophysical Survey Systems, Inc., Radan III software (Galinovsky and Levin 1990) and a model SIR-2 radar connected to a transceiver with a cable approximately $300 \mathrm{ft}$ long. Data from the SIR-2 system were downloaded directly to the personal computer. The control unit/thermal printer was located in the transport vehicle. The computer was located in a field office, so that the radar operator can download, check data quality, and do preliminary processing after a day's run.

Wave-velocity characteristics of near-surface materials were derived from known positions of buried objects. Internal calibration was run at least twice each day to ensure that the graphic record of the range setting was consistent. Studies conducted during the 1991, 1992, and 1993 field seasons indicate wave velocities of 6-7 nsec/ft for near-surface sediment; however, conditions vary with the heterogeneity of the subsurface.

Ground-penetrating-radar is the best method available to determine depth and geometry of objects buried near the surface. The weakness of the method is its limited depth of exploration due to wave-propagating constraints imposed by the electrical properties of soils. The maximum depth of penetration with GPR at Building E2370 was approximately $7 \mathrm{ft}$ below the ground surface. Depths are calculated from known travel times through earth materials found at APG. 


\section{Geophysical Measurements and Surveys}

Gridding of the total magnetic field (G-822L) and time-domain EMF (EM-61) data sets was achieved using SURFER for Windows software, by Golden Software, Inc., Golden, Colorado (1994), with the minimum curvature method. Documentation supplied for the MINC gridding program suggests that grid intervals from one-half to one-fifth of the profile spacing will yield adequate gridding results for data acquired along profiles (Cordell et al. 1992). Thus, a grid interval of $1.25 \mathrm{ft}$ was used for each set of grid data, which represents a grid interval of one-fourth of the profile spacing ( $5 \mathrm{ft}$ ). Following processing and gridding with the SURFER software, anomalies were enhanced by using color-contouring software developed at ANL by Thompson (1994). These color-contour maps are presented in this report. The data set comprises 11,960 magnetic measurements and 2,543 EM-61 measurements. Profile plots of selected GPR traverses are also presented and are part of a data set comprising 1,031 linear $\mathrm{ft}$.

\subsection{Total-Field Magnetics Measurements}

The magnetic field measured around Building E2370 is shown in Figure 3. Also shown in the figure are the locations of sample points, which, due to the density of data collection, appear as solid black lines. Fence lines are plotted as blue lines, and the edges of the gravel road adjacent to the fence are depicted with thick black lines. The magnetic field surrounding Building E2370 is characterized by high contrasts and many strong point anomalies. Magnetic anomalies are associated with wells WBR-90, -91, and -92; Building E2370; and the fence near coordinates $(20,-5)$ and $(30,0)$. A complete list of the significant magnetic anomalies and their corresponding grid locations is given in Table 1 .

The isolated magnetic highs observed near the southern corner of the building at coordinates $(20,15)$ are unexplained. EM-61 anomalies and a small GPR hyperbola are also found in this area.

According to site maps, the observed magnetic high south of Building E2370, between $X=80$ and $X=100$, is located near Building E2371, which was used as a tool shed. No remains of the building were observed by ANL personnel.

The diffuse magnetic high along the perimeter of the survey area may be caused by roadbed material. However, isolated magnetic anomalies probably have a different, and unknown, origins. Unexplained magnetic anomalies are observed at (20, 90); $(30,100) ;(90,30) ;(97,65)$, $(80,95),(108,75),(95,85),(3,45)$ and $(110,83)$. An EMF anomaly is also observed near the magnetic anomaly at $X=30, Y=100$.

Outside of the survey area, subtle point magnetic anomalies are observed near the southern end of each transect [at $(90,11),(115,13)$, and $(122,-3)]$. The cause of these anomalies is unknown. A magnetic anomaly is also observed between $(152,109)$ and $(163,95)$. 

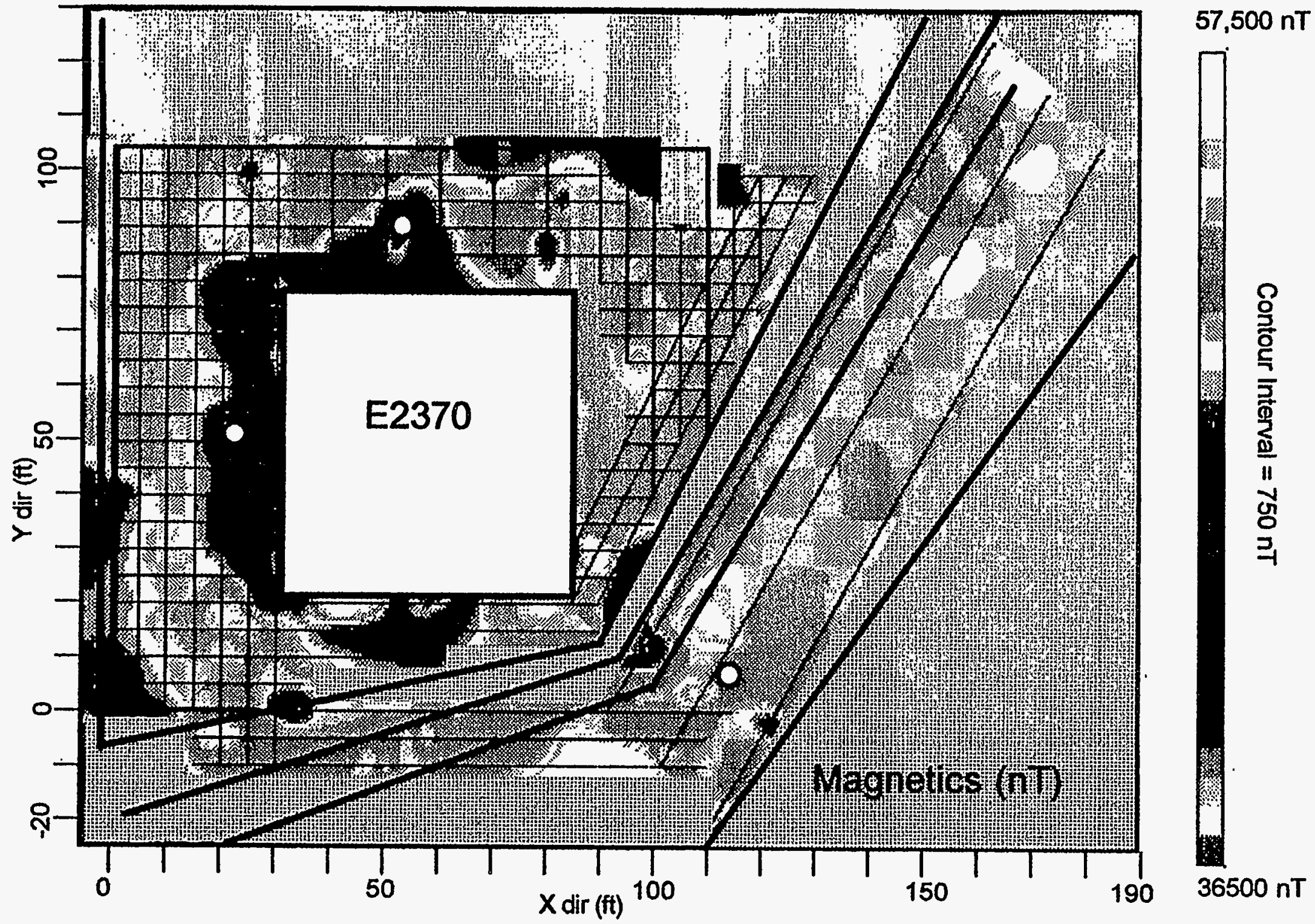

FIGURE 3 Map of the Total Magnetic Field Anomalies at Building E2370 (measured by using a Geometrics G-822L cesiumvapor magnetometer) 
TABLE 1 Location and Description of Geophysical Anomalies Detected Near Building E2370

\begin{tabular}{|c|c|c|c|c|c|}
\hline \multicolumn{2}{|c|}{ Coordinates } & \multicolumn{3}{|c|}{ Geophysical Technique } & \multirow[b]{2}{*}{ Possible Origin } \\
\hline$x$ & $Y$ & Magnetics & EMF & GPR & \\
\hline & & & 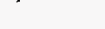 & & \\
\hline 20 & 90 & $x$ & & & Source unknown \\
\hline 30 & 100 & $x$ & $x$ & & Source unknown \\
\hline 90 & 30 & $x$ & & & Source unknown \\
\hline 97 & 65 & $x$ & & & Source unknown \\
\hline 80 & 95 & $x$ & & & Source unknown \\
\hline 108 & 75 & $x$ & & & Source unknown \\
\hline 110 & 83 & $x$ & & & Source unknown \\
\hline 95 & 11 & $x$ & & & Source unknown \\
\hline 115 & 13 & $x$ & & & Source unknown \\
\hline 122 & -3 & $x$ & & & Source unknown \\
\hline $152-163$ & $95-109$ & $x$ & $x$ & & Source unknown \\
\hline 22 & 52 & $x$ & $\mathrm{X}$ & & WBR-90 \\
\hline 54 & 91 & $x$ & $x$ & & WBR-91 \\
\hline 115 & 7 & $x$ & $x$ & & WBR-92 \\
\hline 20 & 15 & $x$ & $x$ & $x$ & Source unknown \\
\hline $80-100$ & -10 & $x$ & & & Former site of Building E2371 \\
\hline $15-101$ & $2-13$ & & $x$ & & Buried. metal pipe \\
\hline $172-189$ & $80-99$ & & $x$ & & Source unknown \\
\hline 42 & 100 & & & $x$ & Source unknown \\
\hline 20 & -5 & $x$ & & & Metal fence \\
\hline 30 & 0 & $x$ & & & Source unknown \\
\hline 95 & 85 & $x$ & & & Source unknown \\
\hline 3 & 45 & $x$ & & . & Source unknown \\
\hline 5 & $47-60$ & & $x$ & & Metal fence \\
\hline $78-110$ & $95-110$ & $x$ & $x$ & & Building E2368 \\
\hline $30-65$ & $100-110$ & $x$ & $x$ & & Building E2364 \\
\hline
\end{tabular}

\subsection{Induced-EMF Measurements}

A color-contour map constructed from EM-61 lower coil data is shown in Figure 4. The positive anomalies centered at $(40,90)$ and $(113,5)$ are probably caused by the nearby wells, WBR-90 and -92. Although the anomalies are not centered on the wells, some positioning error is expected because of surface obstructions at the site. An EMF anomaly is also centered on well WBR-91. The EMF positive in the northeast corner of the survey area is probably caused by metals associated with Building E2368, located north of the survey area. Metallic objects associated with Building E2364, located northwest of Building E2370 (Figure 1), could cause the EMF anomaly along $\mathrm{Y}=105$. 

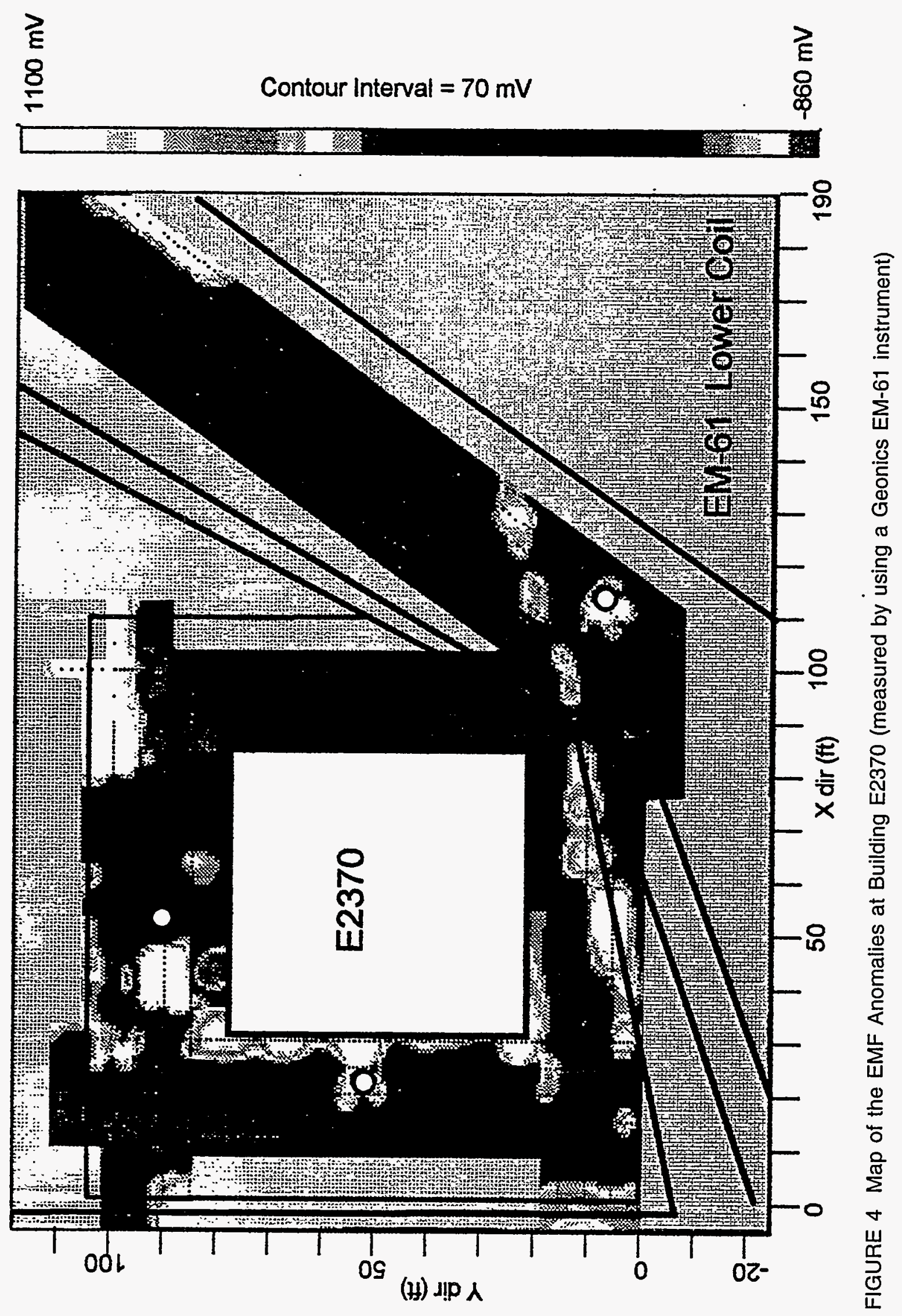
As discussed in Section 3.1, magnetic and EM-61 anomalies are observed $(30,95)$ and $(20,15)$. Along the western edge of the survey area, EMF positive anomalies correlate with the metal fence $(Y=10-15$ and $Y=85-90)$. An opening in the fence between $Y=90$ and $Y=100$ corresponds to an EMF low.

Within the geophysical survey area, an EMF positive trend extends diagonally from $(15,2)$ to about $(101,13)$. Most of the anomaly is produced by the fence; however, an extension of the EMF positive anomaly continues to the northeast, toward the Bush River. Scattered magnetic anomalies are observed in the same general area, but they do not seem to follow the same trend. A GPR anomaly is also located near the south end of one profile. We infer that a lineation, such as a buried metal pipe, lies beneath the area. Because of interference from the fence, it is not known with certainty if the lineation extends beneath the fence to the southwest.

Between the two fences, a low-amplitude EMF high, centered on $(160,100)$ correlates with magnetic observations. A strong EMF anomaly is observed between $(172,80)$ and $(189,99)$. The causes of these anomalies are unknown. A complete list of the significant EMF anomalies and their corresponding grid locations is given in Table 1.

\subsection{Ground-Penetrating-Radar Measurements}

GPR transects were run over the survey area surrounding Building E2370 along east-west and north-south transects spaced $10 \mathrm{ft}$ apart where possible. The locations of GPR lines are shown in the Figure 5 and are also listed in the Attachment, where the lines are numbered in sequence, along with the beginning and ending positions relative to the grid survey. Without verification by another technique or by passing the antenna over an object of known depth, characteristics of radar anomalies may only be inferred. However, where anomalies are also seen with magnetic or resistivity profiling, a diagnostic interpretation of the radar anomaly is possible.

Prior to running the production lines for the survey, replicate runs were made over the same line to determine which of the three transceivers, the $100-, 300-$, or $500-\mathrm{MHz}$ antenna, was best suited to study the terrain surrounding the site. The transceiver providing the best penetration and resolution of buried objects was the $300-\mathrm{MHz}$ unit. Different range settings were also tested over the same transect to determine the optimum resolution and depth of penetration. A range setting of $70 \mathrm{~ns}$, at a scan rate of 32 scans per second, was used for the entire survey. Due to near surface heterogeneities at the site, the gain of the instrument was forced to be low. Consequently, penetration from GPR surveys was limited to a depth of about $3.5 \mathrm{ft}$.

Figure 6 shows an example of GPR observations along $Y=15$. Although strong magnetic and EMF anomalies are observed at about $(25,15)$, a small hyperbola is observed $\mathrm{X}=22$ at about a 2 - $\mathrm{ft}$ depth. Another small hyperbola was detected at $(42,100)$; however, this anomaly has not been verified with other geophysical data.

Between the two fences, three GPR profiles were conducted, and better resolution was generally achieved (Figure 7). On one profile, a GPR anomaly loosely correlates with the linear 


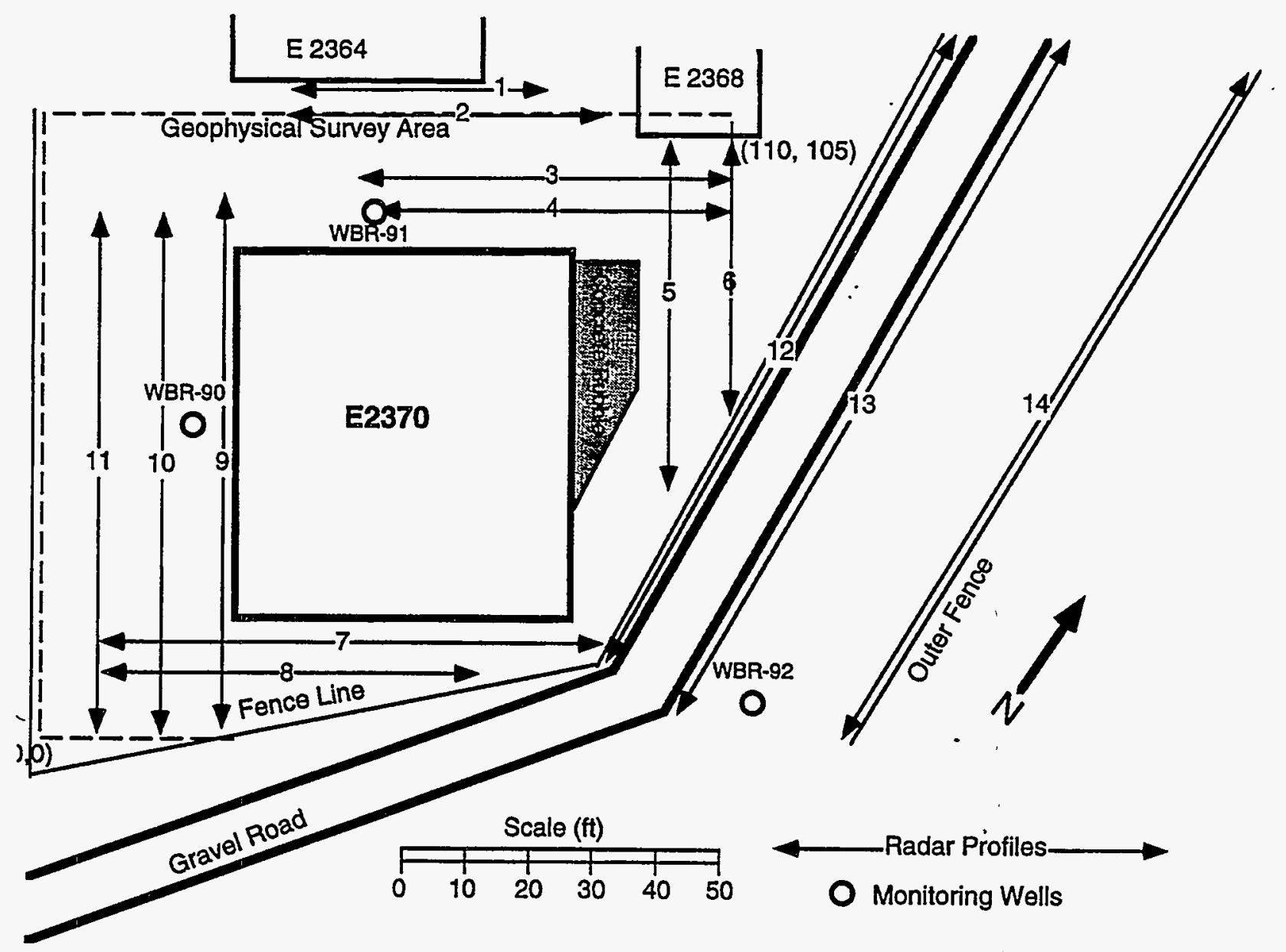

FIGURE 5 Locations of Ground-Penetrating-Radar Profiles 


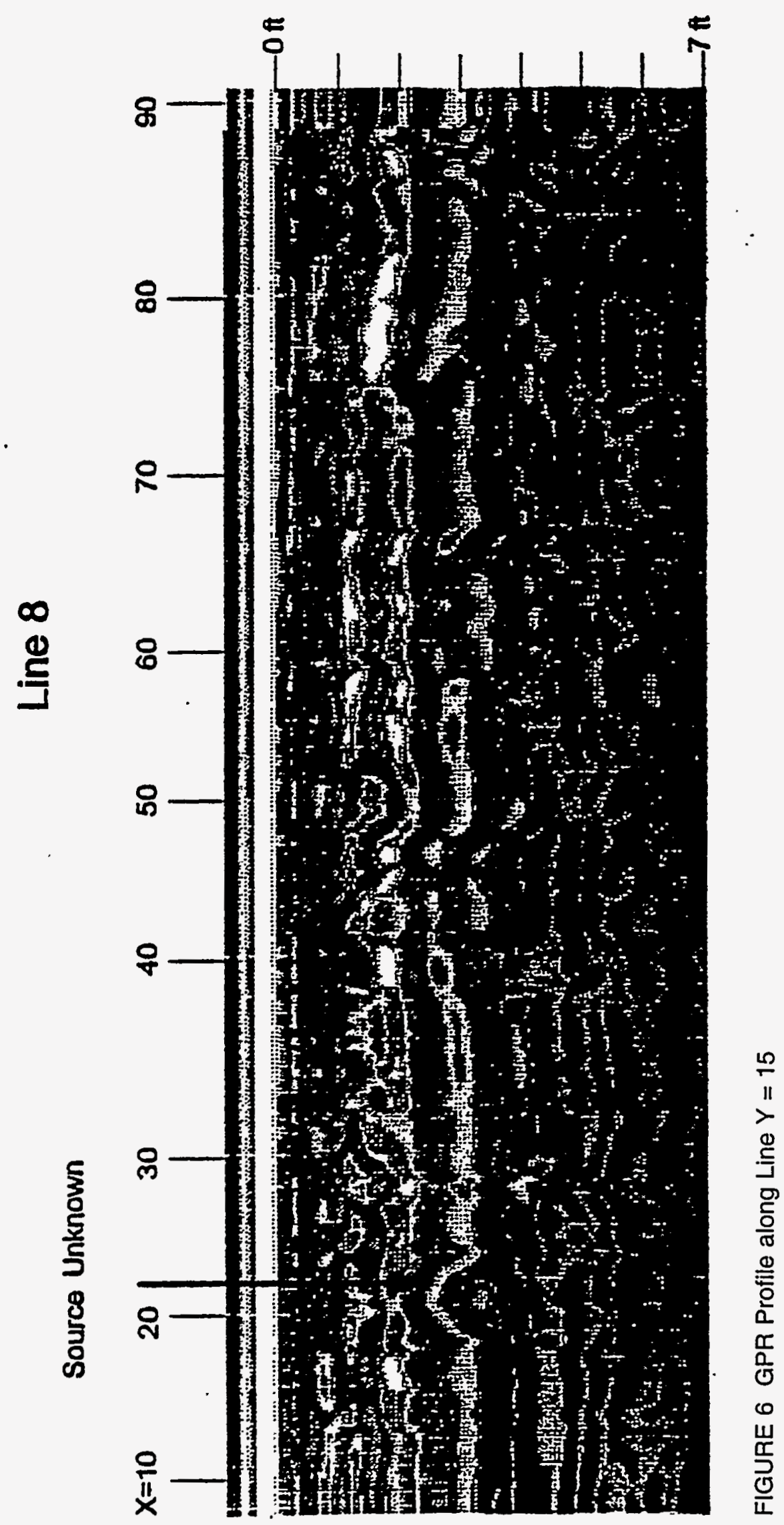




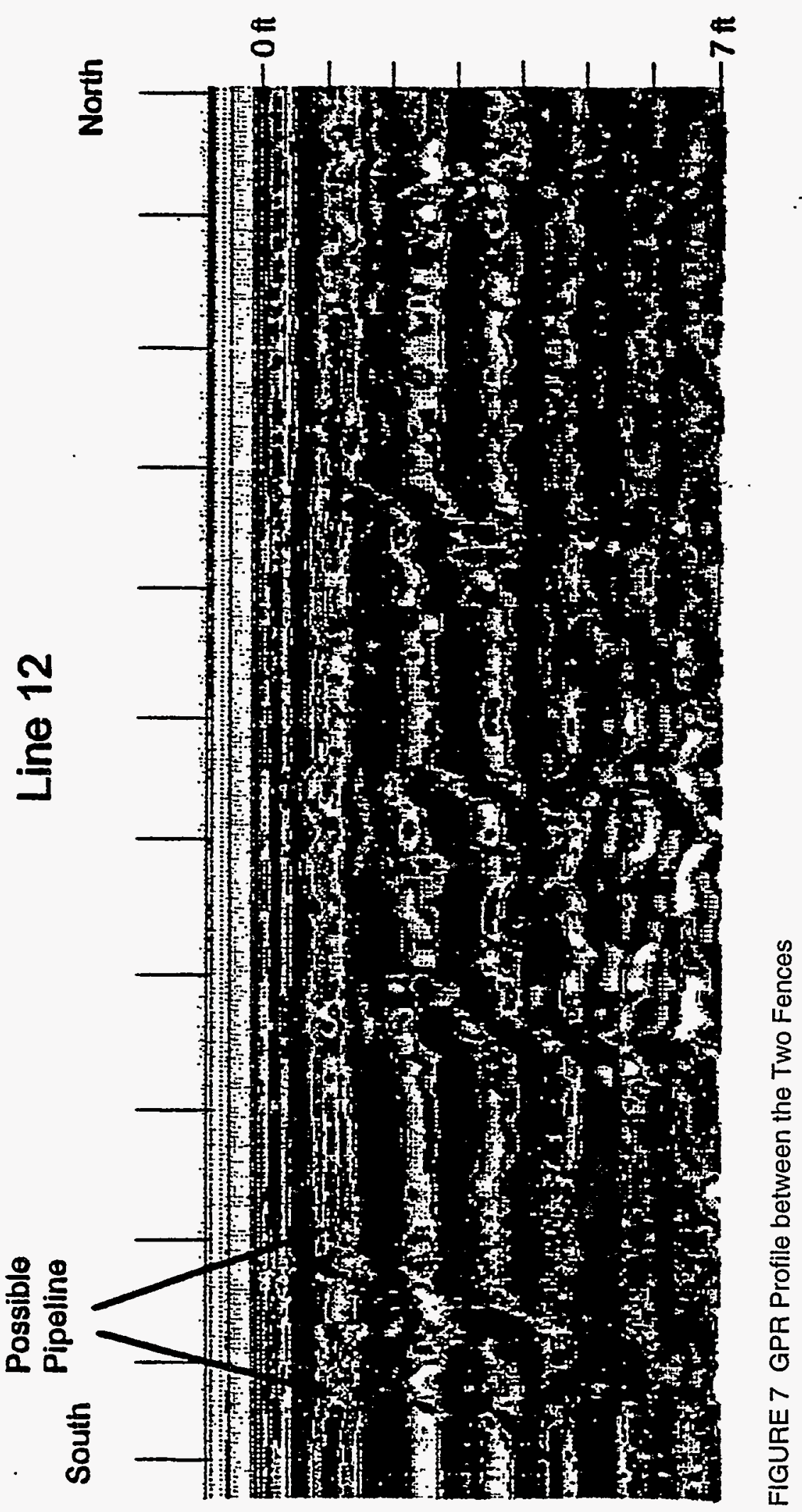


EMF anomaly observed in the area. In addition, scattered point magnetic anomalies are also observed nearby. Although spatial control is limited, these observations suggest that a lineation, such as a buried pipe, may exist in this region.: ' 


\section{Discussion}

A strong correlation exists between EMF and magnetic observations throughout the area. EMF and magnetic highs surrounding Building E2370 suggest the presence of metallic materials (such as rebar-reinforced concrete). Conductivity lows surround Building E2370, implying that the foundation is underlain by unsaturated high-porosity materials. GPR detected anomalous material beneath the foundation to a depth of about $3 \mathrm{ft}$. Within the study area, geophysical observations give no indication of buried pipes, trenches, or sewer lines.

Near the southwest corner of Building E2370, magnetic and EMF highs suggest the presence of buried metallic material. A weak GPR anomaly is also observed in this region.

Magnetic and EMF anomalies are also observed near the concrete associated with the observation tower and near the slabs southeast of Building E2370. In this area, a weak magnetic low at $(145,125)$ correlates with GPR observations, but the source of this anomaly is unknown.

Anomalies are present in the magnetic, conductivity, and EMF profiles that were run parallel to the beach east of Building E2370, suggesting the presence of buried metallic objects. These anomalies are low in amplitude and were not observed on GPR profiles. 


\section{Conclusions}

Geophysical surveys around Building E2370 permit the following conclusions:

1. Geophysical observations within the primary geophysical survey area show no evidence of buried pipes, trenches, or sewer lines.

2. Northeast of Building E2370 between two fences, an EMF lineation is detected that could be produced by a buried metal pipe. Magnetic and GPR anomalies are also observed nearby. This lineation may also extend beneath the fence southwest of Building E2370, although possible interference from the metals in the fence precludes this interpretation with certainty.

3. Small-diameter magnetic and EMF anomalies correlate throughout much of the survey area. Other magnetic anomalies exist, but they do not correlate with the EMF observations. The sources of these anomalies are unknown.

4. A strong magnetic anomaly correlates with a broad, low-amplitude EMF anomaly near $(160,100)$. A strong EMF anomaly is also observed between $(172,80)$ and $(189,99)$. The cause of these anomalies is also unknown. 


\section{References}

Benson, M.A., et al., 1995, unpublished information, Argonne National Laboratory, Argonne, Ill.

Cordell, L., J.D. Philips, and R.H. Godsen, 1992, Potential Field Geophysical Software: Version 2, Open-File Report 92-18, U.S. Geological Survey.

Daudt, C.R., et al., 1995, unpublished information, Argonne National Laboratory, Argonne, Ill.

EAI Corporation, 1989, Historical Records Search and Site Survey of Edgewood Area Buildings, Final Report, prepared by EAI Corporation, Abington, Md., for U.S. Army Chemical Research, Development, and Engineering Center, Aberdeen Proving Ground, Md., under contract No. DAA15-87-D0021.

Galinovsky, L., and K. Levin, 1990, Radan III, Geophysical Survey Systems, Inc., North Salem, N.H.

Golden Software, Inc., 1991, SURFER Version 4, Golden, Colo.

McGinnis, L.D., and S.F. Miller, 1991, Interim Progress Report - Geophysics: Building E5032 Decommissioning, Aberdeen Proving Ground, ANL/ESD/TM-20, Argonne National Laboratory, Argonne, Ill.

McGinnis, L.D., et al., 1992a, Interim Progress Report - Geophysics: Building E5440 Decommissioning, Aberdeen Proving Ground, ANL/ESD/TM-42, Argonne National Laboratory, Argonne, Ill.

McGinnis, L.D., et al., 1992b, Geophysical Study of the Building 103 Dump, Aberdeen Proving Ground, ANL/ESD/TM-51, Argonne National Laboratory, Argonne, Ill.

McGinnis, L.D., et al., 1994, Environmental Geophysics: Buildings E5485, E5487, and E5489 Decommissioning - The "Ghost Town" Complex, Aberdeen Proving Ground, Maryland, ANL/ESD/TM-78, Argonne National Laboratory, Argonne, Ill.

McGinnis, L.D., et al., 1995, Interim Progress Report - Environmental Geophysics: Building E3640 Decommissioning, Aberdeen Proving Ground, Maryland, ANL/ESD/TM-84, Argonne National Laboratory, Argonne, III.

McGinnis, M.G., et al., 1992a, Interim Progress Report - Geophysics: Building E5375 Decommissioning, Aberdeen Proving Ground, ANL/ESD/TM-37, Argonne National Laboratory, Argonne, Ill.

McGinnis, M.G., et al., 1992b, Interim Progress Report - Geophysics: Decommissioning of Buildings E5974 and E5978, Aberdeen Proving Ground, ANL/ESD/TM-47, Argonne National Laboratory, Argonne, Ill. 
Miller, S.F., et al., 1992a, Interim Progress Report - Geophysics: Building E5190 Decommissioning, Aberdeen Proving Ground, ANL/ESD/TM-33, Argonne National Laboratory, Argonne, Ill.

Miller, S.F., et al., 1992b, Interim Progress Report - Geophysics: Building E5476 Decommissioning, Aberdeen Proving Ground, ANL/ESD/TM-43, Argonne National Laboratory, Argonne, Ill.

Nemeth, G., 1989, RCRA Facility Assessment Report, Edgewood Area, Aberdeen Proving Ground, Maryland, 21010-5422, No. 39-26-0490, United States Army Environmental Hygiene Agency, Aberdeen Proving Ground, Md.

Oliveros, J.P., and D.A. Vroblesky, 1989, Hydrogeology of the Canal Creek Area, Aberdeen Proving Ground, Maryland, U.S. Geological Survey, Water-Resources Investigations Report 89-4021.

Thompson, M., 1994, COLMX software, unpublished.

Thompson, M.D., et al., 1992a, Interim Progress Report - Geophysics: Building E5282 Decommissioning, Aberdeen Proving Ground, ANL/ESD/TM-36, Argonne National Laboratory, Argonne, Ill.

Thompson, M.D., et al., 1992b, Interim Progress Report - Geophysics: Building E5481 Decommissioning, Aberdeen Proving Ground, ANL/ESD/TM-44, Argonne National Laboratory, Argonne, Ill.

Thompson, M.D., et al., 1994, Interim Progress Report Addendum - Environmental Geophysics: Building E5032 Decommissioning, Aberdeen Proving Ground, January 1994 Resurvey, ANL/ESD/TM-85, Argonne National Laboratory, Argonne, Ill.

Thompson, M.D., et al., 1995, unpublished information, Argonne National Laboratory, Argonne, Ill. 
Attachment:

Ground-Penetrating-Radar Line Coordinates for Building E2370 
Attachment:

\section{Ground-Penetrating-Radar Line Coordinates for Building E2370}

\begin{tabular}{|c|c|c|c|c|}
\hline \multirow[b]{2}{*}{ Line No. } & \multicolumn{2}{|c|}{ Start Coordinates } & \multicolumn{2}{|c|}{ End Coordinates } \\
\hline & North & East & North & East \\
\hline 1 & 105 & 80 & 105 & 40 \\
\hline 2 & 100 & 90 & 100 & 40 \\
\hline 3 & 90 & 110 & 90 & 50 \\
\hline 4 & 85 & 110 & 52 & 85 \\
\hline 5 & 100 & 100 & 40 & 100 \\
\hline 6 & 90 & 110 & 55 & 110 \\
\hline 7 & 15 & 90 & 15 & 10 \\
\hline 8 & 10 & 70 & 10 & 10 \\
\hline 9 & 0 & 30 & 88 & 30 \\
\hline 10 & 0 & 20 & 85 & 20 \\
\hline 11 & 0 & 10 & 85 & 10 \\
\hline 12 & 92 & 12 & 146 & 112 \\
\hline 13 & 102 & 5 & 163 & 111 \\
\hline 14 & 128 & 0 & 190 & 110 \\
\hline
\end{tabular}


